\title{
HUBUNGAN ANTARA PERILAKU MENONTON FILM KEKERASAN DENGAN PERILAKU AGRESI REMAJA
}

\author{
The Behavior of Adolescents in Watching Violent Films
}

\author{
Nando $^{*)}$ dan Nurmala K. Pandjaitan \\ Departemen Sains Komunikasi dan Pengembangan Masyarakat, Fakultas Ekologi Manusia, IPB \\ *) Email : nando@gmail.com
}

Diterima 6 Januari 2012 / Di 2 April 2012

\begin{abstract}
In recent years many scenes of violence shown in films. Fights, beatings, murders, destructive, and harmful to others has always appeared in the film. Increasing the proportion of violent scenes in movies gave the negative influence of criticism for the audience. Anxiety about the emergence of negative influence is increasing due to the characteristics of a predominantly adolescence audience. One of the alleged negative impact on adolescence movies is aggression behavior. The purpose of this study were (a) know the behavior of adolescents in watching violent films (b) know the behavior of adolescents in the act of aggression (c) analyze the relationship between adolescent behavior in watching violent films with aggression behavior. The research subjects were 45 student of SMK Pelita Ciampea, Bogor. Research data are analyzed using Chi Square with contingency coefficient $(C)$ ranges from 0-1. Behavior watching violent films do not have a significant relationship with the behavior of adolescent aggression. Intensity factor to aggression behavior in the family environment, in the neighborhood and situational factors has a significant relationship to adolescent aggression behavior at $\alpha 0.01$ with 99 percent confidence interval so that a positive relationship. Intensity factor to aggression behavior by friends to have a significant relationship with adolescent aggression behavior at $\alpha 0.05$ with 95 percent confidence interval so that a positive relationship.
\end{abstract}

Keywords: adolescence, agression behavior, and violence film

\section{PENDAHULUAN}

\section{Latar Belakang}

Media komunikasi massa di waktu ini, dengan dukungan berbagai peralatan yang semakin canggih, berkembang dengan pesat untuk memenuhi berbagai kebutuhan manusia. Selama ini media massa memegang peranan sebagai sumber informasi yang sangat penting bagi masyarakat. Bahkan, menurut McLuhan, media massa bisa dikatakan sebagai perpanjangan alat indra manusia (Rakhmat, 2005).

Media komunikasi massa sanggup menampilkan informasi, baik itu tentang benda, orang-orang, atau tempat-tempat yang belum tentu dapat dialami secara langsung oleh penontonnya. Contohnya, ketika seseorang sedang membaca surat kabar, ia dapat mengetahui berbagai permasalahan yang tengah melanda di berbagai negara lain. Dengan membaca buku, seseorang juga bisa merasa dibawa ke sebuah tempat dimasa lalu untuk mengenal sebuah sejarah, atau dengan menonton sebuah film, seseorang dapat diajak masuk ke dalam pengalamanpengalaman imajiner tanpa batas.

Namun media massa memiliki keterbatasan, yaitu bahwa realitas yang ditampilkan oleh media adalah sebuah realitas yang sudah melalui proses seleksi. Media massa, baik itu koran, televisi, maupun film telah menampilkan realitas tangan kedua (second hand reality). Bahkan media massa bukan menyajikan realitas kedua, tetapi karena distorsi, media massa juga "menipu" manusia dengan memberikan citra dunia yang keliru. Pada akhirnya, sekalipun komunikasi tidak secara langsung menimbulkan perilaku tertentu. tetapi cenderung akan mempengaruhi komunikan dalam mengorganisasikan citra tentang lingkungan, dan citra inilah yang akan mempengaruhi komunikan dalam berperilaku (Rakhmat, 2005). Jika hal tersebut tidak segera disadari, maka media massa akan membentuk citra khalayaknya ke arah yang dikehendaki media tersebut. Film memerlukan media lain untuk dapat ditonton oleh khalayak. Media Film dapat berupa proyektor dalam gedung bioskop, tayangan televisi, DVD/CD yang diputar melalui DVD/VCD player, komputer, atau laptop dan koneksi internet dengan "streaming" melalui situs mengunakan komputer atau laptop.

Beberapa tahun terakhir ini adegan kekerasan banyak ditayangkan dalam film. Perkelahian, pemukulan, pembunuhan dan sebagainya yang merusak dan merugikan orang lain selalu muncul dalam film. Tingkat kekerasan dalam film terus meningkat dalam kualitas dan kuantitas (Widiastuti, 2002). Meningkatnya proporsi 
adegan kekerasan dalam film-film melahirkan kecaman akan timbulnya pengaruh negatif bagi penonton. Anggadewi Moesono (1996) dalam Evita (2007) mengatakan film tidak langsung mempengaruhi perilaku penonton tetapi kalau "bertubi-tubi" disajikan akan berdampak negatif bagi penonton. Kecemasan akan munculnya pengaruh negatif semakin bertambah karena karakteristik penonton yang didominasi remaja, di mana remaja merupakan individu yang mudah di pengaruhi dan meniru model atau perilaku yang ditunjukkan dalam film (Evita, 2007).

Salah satu dampak negatif film pada remaja adalah perilaku agresi. Perilaku agresi menurut Baron (Koeswara, 1988) adalah tingkah laku yang ditunjukkan untuk melukai dan mencelakakan individu lain yang tidak menginginkan datangnya tingkah laku tersebut. Namun hanya dengan menonton adegan kekerasan di film saja orang tidak langsung akan menjadi agresi. Menurut Raymond Bavor Little John dalam Valentine (2009) media massa tidak langsung menimbulkan dampak bagi khalayak. Nyatanya banyak variabel terlibat dalam proses terjadinya efek. Hal ini didukung oleh Klapper yang menyatakan bahwa media massa hanya sebagai "contributing cause" (Widiastuti, 2009). Rakhmat (2005) menyatakan bahwa komunikasi massa terjadi lewat serangkaian perantara. Komunikasi antara lain melalui pengaruh media massa. Untuk sampai kepada perilaku tertentu, maka pengaruh ini diseleksi, disaring, atau bahkan mungkin ditolak sesuai dengan faktor-faktor personal yang mempengaruhi reaksi khalayak, faktor situasional di mana individu berada, dan situasi lingkungan, baik primer (keluarga) atau sekunder (lingkungan masyarakat).

Contoh perilaku agresi akibat menonton film kekerasan yang baru-baru ini terjadi yakni pada kasus kejahatan yang dilakukan remaja yang bernama Andrew Conley, ia mencekik adiknya yang bernama Conner berusia 10 tahun hingga tewas. Conner dicekik selama 20 menit dan setelah meninggal tubuhnya dibungkus dengan tas sampah dan dibuang di tempat parkir dekat rumah mereka di Rising Sun, India. Setelah pembunuhan itu, Andrew menyetir mobil ke rumah pacarnya untuk menonton sebuah film. Andrew mengaku membunuh sang adik karena ingin meniru karakter Dexter pada pemeriksaan polisi seperti dilansir Dailymail pada tanggal 16 September 2010. Andrew mengidentifikasikan dirinya sebagai Dexter Morgan yang dalam filmnya diperankan oleh Michael C. Hall. Dexter adalah film seri televisi Amerika yang diadaptasi dari novel Darkly Dreaming Dexter yang ditulis Jeff Lindsay. Film ini mengisahkan Dexter, seorang polisi ahli forensik di kantor polisi Miami ${ }^{1}$. Di balik pekerjaanya sebagai polisi, Dexter ternyata juga seorang pembunuh berantai. Film ternyata memiliki hubungan dengan perilaku remaja, maka penelitian ini akan dilihat apakah hubungan perilaku remaja menonton film kekerasan dengan perilaku agresi.

\footnotetext{
${ }^{1}$ Iin Yumiyanti: Film "Dexter" Menginspirasi Remaja Bunuh Adiknya Sendiri, 20 Januari 2011, http://movie.detikhot.com/read/2010/09/16/134029/14417 08/229/film--dexter--menginspirasi-remaja-bunuhadiknya-sendiri
}

\section{Perumusan Masalah}

Masalah yang akan ditelaah dalam penelitian ini adalah

a. Bagaimana remaja dalam berperilaku menonton film kekerasan?

b. Bagaimana remaja dalam berperilaku agresi?

c. Apakah ada hubungan antara perilaku remaja dalam menonton film kekerasan dengan perilaku agresi?

\section{Tujuan Penelitian}

a. Mengetahui remaja dalam berperilaku menonton film kekerasan.

b. Mengetahui remaja dalam berperilaku agresi.

c. Menganalisa hubungan antara perilaku remaja dalam menonton film kekerasan dengan perilaku agresi.

\section{Kegunaan Penelitian}

a. Bagi akademisi, Penelitian ini dapat menjadi sumber informasi dan referensi baru untuk dilakukan penelitian lebih lanjut mengenai perilaku remaja menonton film kekerasan dan perilaku agresi remaja.

b. Bagi Masyarakat, mengetahui informasi mengenai pengaruh film kekerasan terhadap perilaku agresi remaja.

c. Bagi pemerintah, mengetahui bahaya pengaruh film kekerasan terhadap perilaku agresi remaja sehingga melakukan pengawasan dan pembatasan film-film kekerasan.

\section{PENDEKATAN TEORITIS}

\section{Tinjauan Pustaka}

\section{Film}

Menurut undang-undang Republik Indonesia No.8 tahun 1992 tentang perfilman, film adalah karya cipta seni dan budaya yang merupakan media komunikasi massa pandang-dengar yang dibuat berdasarkan asas sinematografi dengan direkam pada pita seluloid, pita video, piringan video, dan/atau bahan hasil penemuan teknologi lainnya dalam segala bentuk, jenis, dan ukuran melalui proses kimiawi, proses elektronik, atau proses lainnya, dengan atau tanpa suara, yang dapat dipertunjukkan dan/atau ditayangkan dengan sistem proyeksi mekanik, elektronik, dan/atau lainnya. Film berperan sebagai sarana baru yang digunakan untuk menyebarkan hiburan yang sudah menjadi kebiasaan terdahulu, serta menyajikan cerita, peristiwa, musik, drama, lawak dan sajian teknis lainnya kepada masyarakat umum (McQuail, 1987). Jenis-jenis film menurut Sumarno (1996), yaitu:

\section{a. Film cerita}

Film cerita memiliki perbagai jenis atau genre. Dalam hal ini. genre diartikan sebagai jenis film yang ditandai oleh gaya. bentuk atau isi tertentu. Ada yang disebut film drama, film horror, film perang. film sejarah, film fiksiilmiah, film komedi film laga, film khayalan dan film koboi. Penggolonggan jenis film tidaklah ketat karena sebuah film dapat dimasukkan ke dalam beberapa jenis. 
Misalnya sebuah film komedi-laga, dan film dramasejarah. Jenis-jenis film cerita itu agar tetap bertahan hidup harus tanggap terhadap perkembangan jaman. Jadi, cerita adalah bungkus atau kemasan yang memungkinkan pembuat film melahirkan realitas rekaan yang merupakan suatu alternatif dari realitas nyata bagi penikmatnya. Dari segi komunikasi, ide atau pesan yang dibungkus oleh cerita itu merupakan pendekatan yang bersifat membujuk (persuasive).

\section{b. Film noncerita}

Film cerita memiliki berbagai jenis, demikian pula yang tergolong pada film noncerita. Namun, pada mulanya hanya ada dua tipe film noncerita ini, yakni yang termasuk daiam film dokumenter dan film faktual. Film faktual umumnya hanya menampilkan fakta dan kamera sekadar merekam peristiwa. Film faktual ini di zaman sekarang tetap hadir dalam bentuk sebagai film berita dan film dokumentasi. Film berita menitikberatkan pada segi pemberitaan suatu kejadian aktual, misalnya film berita yang banyak terdapat dalam siaran televisi. Sementara itu, film dokumentasi hanya merekam kejadian tanpa diolah lagi, misalnya dokumentasi peristiwa perang, dan dokumentasi upacara kenegaraan.

\section{c. Film eksperimental dan film animasi}

Selain pembagian besar film cerita dan noncerita masih ada cabang pembuatan film yang disebut film eksperimental dan film animasi. Film eksperimental adalah film yang tidak dibuat dengan kaidah-kaidah pembuatan film yang lazim. Tujuannya untuk mengadakan eksperimental dan mencari cara-cara pengucapan baru lewat film. Sementara itu, film animasi memanfaatkan gambar maupun benda-benda mati yang lain, seperti boneka, Meja, dan kursi yang bisa dihidupkan dengan teknik animasi. Prinsip teknik animasi sama dengan pcmbuatan film dengan subjek yang hidup, yang memerlukan dua puluh empat gambar perdetik untuk menciptakan ilusi gerak. Sedikit banyaknya gambar perdetik itu menentukan kasar dan halus pada ilusi gerak yang tercipta. Film animasi dengan materi rentetan lukisan di kertas yang kemudian lebih dikenai dengan sebutan film kartun yang terbanyak diproduksi di manamana.

Penelitian ini membatasi tema film yang akan diteliti, yakni film kekerasan. Film kekerasan adalah film yang berisi banyak adegan kekerasan (baik itu kekerasan verbal, fisik, dan kekerasan yang menggunakan intrumental) sebagai temanya. Jenis film kekerasan yang sering ditonton berupa film cerita. Film cerita ini mempunyai banyak genre.

Genre film kekerasan yang sering ditonton bermacammacam dan tidak hanya terdiri satu genre saja, dapat terdiri dari dua sampai tiga genre. Genre film kekerasan yang sering ditonton ${ }^{2}$, yakni:

\footnotetext{
${ }^{2}$ Tim Dirks: Filmsite, 20 Januari 2011, http://www.filmsite.org/filmgenres.html
}

\section{a. Film action/laga}

Film action/laga biasanya memerlukan anggaran besar dengan adegan mengejar, menyelamatkan, pertempuran, perkelahian, melarikan diri, gerakan spektakuler dan petualangan untuk membuat penonton terkagum.

\section{b. Film perang}

Film yang berupa pertarungan yang sebenarnya berperang melawan bangsa-bangsa atau manusia di darat, di laut, atau di udara dengan memberikan latar belakang film action/laga. Perang film sering dipasangkan dengan genre lain, seperti action/laga, petualangan, drama, romantika, ketegangan, dan mereka sering mengambil pendekatan ke arah peperangan.

\section{c. Film horor}

Film Horor dirancang untuk menakut-nakuti dengan bersembunyi dan seringkali dalam kejutan yang menakutkan tetapi menghibur kita pada saat yang sama. Film Horor menampilkan berbagai macam gaya dari yang klasik seperti monster dan manusia gila. Mereka sering digabungkan dengan fiksi ilmiah seperti ketika bumi terancam oleh alien. Ada banyak sub-genre horor yaitu teror remaja, pembunuh berantai, setan, drakula, frankenstein.

\section{d. Film kungfu/silat}

Film yang berisi adegan perkelahian antara satu orang atau lebih dengan memamerkan seni bela diri.

\section{e. Film thriller}

Sebuah genre film yang mengunakan ketegangan dan kegembiraan sebagai elemen utama dalam temanya.

\section{f. Film detektif-misteri}

Film yang berfokus pada tindak pidana/kejahatan yang belum terpecahkan (biasanya pembunuhan, hilangnya satu atau lebih karakter dalam film, atau pencurian). Pada karakter utama yakni detektif dianggap pahlawan, dia memecahkan solusi dari sebuah kasus kejahatan.

\section{g. Film kriminalitas}

Film kriminalitas (gangster) dikembangkan berdasarkan tindakan-tindakan kejahatan dari penjahat atau mafia, khususnya perampokan bank atau penjahat kejam yang beroperasi di luar hukum, mencuri dan membunuh sebagai jalan mereka menempuh kehidupan. Kategori ini pada umumnya berisi penjelasan tentang berbagai film pembunuh berantai.

\section{Film Sebagai Media Komunikasi Massa}

Komunikasi massa menurut Mulyana (2004) adalah komunikasi yang menggunakan media massa, baik cetak (surat kabar, majalah) atau elektronik (radio, televisi, film) yang dikelola oleh lembaga atau orang yang dilembagakan, ditujukan kepada sejumlah besar orang yang tersebar di banyak tempat, anonim, dan heterogen.

Oleh karena itu, pesan-pesan dalam komunikasi massa bersifat umum, disampaikan secara cepat, dan selintas (khususnya media elektronik). Sedangkan menurut Rakhmat (2005) komunikasi massa adalah komunikasi melalui media massa, yakni suratkabar, majalah, radio, 
televisi, dan film. Sebagai salah satu media komunikasi massa, film mempunyai ciri-ciri sebagai berikut (Effendy, 2001):

\section{Pesan dalam film berlangsung satu arah}

Tidak ada arus balik antara komunikan dan komunikator. Sutradara film sebagai komunikator tidak mengetahui tanggapan khalayak terhadap pesan dalam film yang dibuatnya. Sutradara tidak mengetahui apakah khalayak suka atau tidak terhadap film yang dibuatnya. Sutradara mengetahui film yang disukai khalayak melalui penjualan tiket bioskop dan DVD film yang dibuatnya. Semakin banyak tiket bioskop dan DVD film terjual berarti khalayak menyukai film tersebut.

\section{Komunikator film melembaga}

Dalam pembuatan film melibatkan sejumlah orang yang terkoordinasi yang memiliki peran yang berbeda-beda, seperti produser, sutradara, artis dan kru film lainnya.

\section{Pesan film bersifat umum.}

Pesan yang disampaikan film bersifat umum karena ditujukan untuk khalayak banyak.

\section{Menimbulkan keserempakan}

Keserempakan dalam film terlihat ketika film dibuat untuk ditonton oleh khalayak secara serempak.

\section{Komunikan film bersifat heterogen}

Khalayak film merupakan kumpulan anggota masyarakat yang keberadaannya terpencar, berbeda-beda satu sama lainnya. Oleh karena itu film dibuat dalam berbagai bahasa.

Secara umum, fungsi film dapat dilihat dari fungsi komunikasi massa. Dominick (1983) dalam Evita (2007) mengemukakan fungsi komunikasi massa sebagai berikut:

1. Pengawasan (surveillance), yang dapat di bagi menjadi dua jenis, yaitu:

a. Pengawasan peringatan (warning or beware surveillance) yang terjadi jika media menyampaikan informasi yang harus disampaikan segera dan serentak (informasi bencana alam, perang, dan kecelakaan), atau informasi mengenai ancaman dalam jangka waktu lama atau ancaman kronis (informasi polusi udara). Media yang sangat berperan dalam peringatan ini yaitu surat kabar, radio, dan televisi. Film tidak mempunyai fungsi pengawasan peringatan karena film bersifat tidak langsung dan segera, di mana proses pembuatan film memerlukan jangka waktu lama.

b. Pengawasan instrumental (instrumental surveillance), berkaitan dengan penyebaran informasi yang berguna bagi kehidupan seharihari dimana tidak semua informasi ini menjadi berita. Fungsi ini dapat dijumpai pada isi media yang dimaksudkan untuk menghibur seperti film. Beberapa pengawasan instrumetal dalam film berupa mode pakaian terbaru dan isu-isu sosial.

\section{Interpretasi (interpretation)}

Media tidak hanya menyajikan fakta dan data, tetapi juga informasi beserta interprestasi mengenai suatu peristiwa tertentu. Interprestasi ini oleh media film sering dilakukan pada film-film sejarah atau film yang diangkat dari kisah nyata.

\section{Hubungan (linkage)}

Media mampu menghubungkan unsur-unsur yang terdapat di dalam masyarakat yang tidak bisa dilakukan secara langsung oleh saluran perseorangan. Fungsi hubungan yang dimiliki media sedemikian berpengaruhnya pada masyarakat sehingga dijuluki public making ability of the mass media atau kemampuan membuat sesuatu menjadi umum dari media massa. Film mampu menghubungkan semua unsur yang terdapat dalam masyarakat, bahkan unsur-unsur yang mustahil sekalipun menjadi kesatuan cerita utuh, dam kemudian dianggap sebagai hal yang nyata.

\section{Sosialisasi}

Sosialisasi merupakan transmisi nilai-nilai yang mengacu kepada seseorang mengadopsi perilaku dan nilai-nilai dari suatu kelompok. Media massa menyajikan penggambaran masyarakat, dan dengan membaca, mendengar, dan menonton, maka seseorang mempelajari bagaimana khalayak berperilaku dan nilai-nilai penting. Banyak remaja belajar tentang perilaku agresi dari menonton film kekerasan dan tayangan televisi yang mengisahkan tentang kekerasan.

\section{Hiburan (entertainment)}

Fungsi ini jelas tampak pada televisi, film, dan rekaman suara, bahkan hiburan merupakan fungsi utama dari film. Tujuan fungsi ini untuk mengurangi rasa bosan, ketegangan pikiran, atau melarikan diri dari tekanan dan masalah.

Menurut undang-undang Republik Indonesia No.8 tahun 1992 tentang perfilman, film sebagai media komunikasi massa mempunyai fungsi :

\section{a. Penerangan}

Film sebagai media yang bisa mempromosikan nilainilai keragaman budaya dan kepribadian bangsa kepada masyarakat internasional.

\section{b. Pendidikan}

Film sebagai media yang mampu menjadi sarana pendidikan bagi khalayak yang menontonnya.

\section{c. Pengembangan budaya bangsa}

Film sebagai media yang mampu memantapkan dan mengembangkan nilai-nilai budaya bangsa.

\section{d. Hiburan}

Film sebagai media yang mampu manjadi sarana penghibur bagi khalayak yang menontonnya. 


\section{e. Ekonomi}

Menumbuhkan dan mengembangkan perfilman sebagai industri yang maju, mengembangkan nilai-nilai budaya, dan mampu bersaing dalam peta internasional.

Dari uraian diatas mengenai fungsi film menunjukkan bahwa film juga berfungsi mempengaruhi, menyampaikan informasi, sosialisasi, dan hiburan. Hal ini menunjukkan film dapat digunakan sebagai saluran untuk memasukkan nilai-nilai baru ke dalam diri masyarakat baik nilai-nilai positif maupun negatif.

\section{Remaja}

Remaja dalam bahasa Latin adalah adolescence, yang artinya "tumbuh atau tumbuh untuk mencapai kematangan". Istilah adolescence sesungguhnya mempunyai arti yang luas, mencakup kematangan mental, emosional, sosial, dan fisik (Hurlock, 1991). Pandangan ini didukung oleh Piaget (Hurlock, 1991) yang mangatakan bahwa secara psikologis remaja adalah suatu usia dimana individu menjadi terintegrasi ke dalam masyarakat dewasa, suatu usia dimana anak tidak merasa bahwa dirinya berada di bawah tingkat orang yang lebih tua melainkan merasa sama, atau paling tidak sejajar. Memasuki masyarakat dewasa ini mengandung banyak aspek afektif, lebih atau kurang dari usia pubertas.

Remaja juga dapat didefinisikan sebagai periode transisi antara masa anak-anak ke masa dewasa, atau masa usia belasan tahun. WHO (World Health Organization) (Sarwono, 2004) memberikan definisi mengenai remaja lebih konseptual, remaja adalah suatu masa dimana:

a. Individu berkembang dari saat pertama kali ia menunjukkan tanda-tanda seksual sekundernya sampai saat ia mencapai kematangan seksual.

b. Individu mengalami perkembangan psikologi dan pola identifikasi dari anak-anak menjadi dewasa.

c. Terjadi peralihan dari ketergantungan sosial-ekonomi yang penuh kepada keaadaan yang relatif lebih mandiri.

Hurlock (1991) membagi masa remaja menjadi masa remaja awal (13 hingga 16 atau tahun) dan masa remaja akhir (16 atau 17 tahun hingga 18 tahun). Masa remaja awal dan akhir dibedakan oleh Hurlock karena pada masa remaja akhir individu telah mencapai transisi perkembangan yang lebih mendekati masa dewasa. Berdasarkan tinjauan teori perkembangan, usia remaja adalah masa saat terjadinya perubahan-perubahan yang cepat, termasuk perubahan fundamental dalam aspek kognitif, emosi, sosial dan pencapaian (Fagan, 2006). Menurut Erickson masa remaja adalah masa terjadinya krisis identitas atau pencarian identitas diri. Karakteristik remaja yang sedang berproses untuk mencari identitas diri ini juga sering menimbulkan masalah pada diri remaja. Pada masa ini remaja mengalami ketidakstabilan dari waktu ke waktu, karena mereka ada dalam masa peralihan dan mereka berusaha menyesuaikan perilaku baru dari fase-fase perkembangan sebelumnya. Gejolak ditimbulkan baik oleh fungsi sosial remaja dalam mempersiapkan diri menuju kedewasaan (mencari identitas diri dan memantapkan posisinya dalam masyarakat); oleh pertumbuhan fisik (perkembangan tanda-tanda seksual sekunder), perkembangan inteligensi (penalaran yang tajam dan kritis), serta perubahan emosi (lebih peka, cepat marah dan agresi).

Pada umumnya permulaan masa remaja ditandai dengan perubahan-perubahan fisik. Bersamaan dengan perubahan fisik maupun psikis, mereka mulai melepaskan diri dari ikatan orang tua dan kemudian terlihat perubahanperubahan kepribadian yang terwujud dalam cara hidup mereka untuk menyesuaikan diri dalam masyarakat (Gunarsa, 1989). Hurlock (1991) menyatakan bahwa lingkungan sosial yang menimbulkan perasaan aman serta keterbukaan yang berpengaruh dalam hubungan sosial. Masa remaja yang identik dengan lingkungan sosial tempat berinteraksi, membuat mereka dituntut untuk dapat menyesuaikan diri secara efektif. Bila aktivitasaktivitas yang dijalani tidak memadai untuk memenuhi tuntutan gejolak energinya, mereka seringkali meluapkan kelebihan energinya ke arah yang negatif, salah satunya adalah muncul perilaku agresi.

Masa remaja merupakan salah satu periode perkembangan yang dialami oleh setiap individu, sebagai masa transisi dari masa kanak-kanak menuju masa dewasa. Masa ini memiliki ciri-ciri tertentu yang membedakan dengan periode perkembangan yang lain. Ciri yang menonjol pada masa ini adalah individu mengalami pertumbuhan dan perkembangan yang amat pesat, baik fisik, emosional dan sosial. Hurlock (1991) pada masa remaja ini ada beberapa perubahan yang bersifat universal, yaitu meningkatnya emosi, perubahan fisik, perubahan terhadap minat dan peran, perubahan pola perilaku, nilai- nilai dan sikap ambivalen terhadap setiap perubahan. Berikut ini dijelaskan satu persatu dari ciri-ciri perubahan yang terjadi pada masa remaja.

\section{a. Perubahan fisik}

Perubahan fisik berhubungan dengan aspek anotomi dan aspek fisiologis, di masa remaja kelenjar hipofesa menjadi masak dan mengeluarkan beberapa hormone, seperti hormone gonotrop yang berfungsi untuk mempercepat kemasakan sel telur dan sperma, serta mempengaruhi produksi hormon kortikortop berfungsi mempengaruhi kelenjar suprenalis, testosterone, oestrogen, dan suprenalis yang mempengaruhi pertumbuhan anak sehingga terjadi percepatan pertumbuhan (Monks dkk, 2000). Dampak dari produksi hormone tersebut Atwater (1992) adalah: (1) ukuran otot bertambah dan semakin kuat. (2) testosteron menghasilkan sperma dan oestrogen memproduksi sel telur sebagai tanda kemasakan. (3) Munculnya tanda-tanda kelamin sekunder seperti membesarnya payudara, berubahnya suara, ejakulasi pertama, tumbuhnya rambut-rambut halus disekitar kemaluan, ketiak dan muka.

\section{b. Perubahan emosional.}

Pola emosi pada masa remaja sama dengan pola emosi pada masa kanak-kanak. Pola-pola emosi itu berupa marah, takut, cemburu, ingin tahu, iri hati, gembira, sedih dan kasih sayang. Perbedaan terletak pada rangsangan yang membangkitkan emosi dan pengendalian dalam mengekspresikan emosi. Remaja umumnya memiliki kondisi emosi yang labil pengalaman emosi yang ekstrem 
dan selalu merasa mendapatkan tekanan (Hurlock, 1991). Bila pada akhir masa remaja mampu menahan diri untuk tidak mengeksperesikan emosi secara ekstrem dan mampu memgekspresikan emosi secara tepat sesuai dengan situasi dan kondisi lingkungan dan dengan cara yang dapat diterima masyarakat, dengan kata lain remaja yang mencapai kematangan emosi akan memberikan reaksi emosi yang stabil (Hurlock, 1991). Nuryoto (1992) menyebutkan ciri-ciri kematangan emosi pada masa remaja yang ditandai dengan sikap sebagai berikut: (1) tidak bersikap kekanak-kanakan. (2) bersikap rasional. (3) bersikap objektif (4) dapat menerima kritikan orang lain sebagai pedoman untuk bertindak lebih lanjut. (5) bertanggung jawab terhadap tindakan yang dilakukan. (6) mampu menghadapi masalah dan tantangan yang dihadapi.

\section{c. Perubahan sosial}

Perubahan fisik dan emosi pada masa remaja juga mengakibatkan perubahan dan perkembangan remaja, Monks, dkk (2000) menyebutkan dua bentuk perkembangan remaja yaitu, memisahkan diri dari orangtua dan menuju kearah teman sebaya. Remaja berusaha melepaskan diri dari otoritas orangtua dengan maksud menemukan jati diri. Remaja lebih banyak berada di luar rumah dan berkumpul bersama teman sebayanya dengan membentuk kelompok dan mengeksperesikan segala potensi yang dimiliki. Kondisi ini membuat remaja sangat rentan terhadap pengaruh teman dalam hal minat, sikap penampilan dan perilaku. Perubahan yang paling menonjol adalah hubungan heteroseksual. Remaja akan memperlihatkan perubahan radikal dari tidak menyukai lawan jenis menjadi lebih menyukai. Remaja ingin diterima, diperhatikan dan dicintai oleh lawan jenis dan kelompoknya.

Dari beberapa pendapat ahli, dapat disimpulkan bahwa remaja adalah masa peralihan antara anak-anak ke dewasa dengan umur berkisar belasan tahun (15 sampai 19 tahun) yang dipengaruhi oleh pertumbuhan faktor biologis dan perkembangan faktor psikologisnya. Pada masa itu, karakteristik remaja yang menimbulkan masalah terhadap dirinya adalah mengalami krisis identitas, ketidakstabilan emosi, dan adanya sikap menentang dan menantang apa saja yang merupakan bagian dari perkembangan faktor psikologisnya.

\section{Perilaku}

Perilaku adalah semua kegiatan atau aktifitas manusia, baik yang dapat diamati langsung maupun yang tidak dapat diamati pihak luar (Notoatmodjo, 2003). Pengertian perilaku menurut Krech, dkk (Suharto, 2006) yaitu pikiran dan tindakan individu untuk merefleksikan keinginan-keinginan (wants) dan tujuan (goals). Berdasarkan uraian pengertian perilaku diatas dapat disimpulkan bahwa perilaku adalah semua kegiatan manusia untuk mencapai tujuannya. Penelitian ini meneliti dua perilaku, yaitu:
a. Perilaku Remaja Menonton Film Kekerasan
b. Perilaku agresi

\section{Perilaku Remaja Menonton Film Kekerasan}

Rosengren (1987) dalam Evita (2007) melihat perilaku penggunaan media terdiri dari jumlah waktu yang digunakan dalam berbagai media, jenis isi media yang dikonsumsi dan berbagai hubungan antara individu konsumen media dengan isi media yang dikonsumsi atau dengan media secara keseluruhan. Lowery dan De Fleur (1993) dalam Evita (2007) menyebutkan tiga hal yang dapat dijadikan sebagai alat ukur perilaku menonton yaitu total waktu menonton, frekuensi menonton, dan pilihan program acara yang ditonton. Total waktu menonton adalah jumlah waktu yang dihabiskan seseorang untuk menonton film, sedangkan frekuensi menonton adalah berapa kali seseorang menonton film dalam jangka waktu tertentu. Pilihan program acara yang ditonton dapat dilihat dari pilihan jenis film yang dipilih untuk ditonton.

Sementara hasil penelitian Budyatna dalam Evita (2007) mengenai perilaku menonton pada remaja menunjukkan dimensi-dimensi perilaku terdiri dari frekuensi (jumlah atau kuantitas dari perilaku), motif atau alasan seseorang berperilaku, jenis tontonan, dan hubungan antara individu dengan isi media. Evita (2007) dalam penelitiannya tentang perilaku menonton film pada remaja menunjukkan bahwa perilaku menonton film dipengaruhi oleh frekuensi menonton film, jenis film yang ditonton, dan motif menonton film sedangkan Ida Tumengkol (2009) menyebutkan perilaku menonton hanya dilihat dari frekuensi menonton dan motif menonton.

Dari uraian di atas, maka perilaku menonton film kekerasan dapat dilihat dari:

\section{a. Intensitas menonton film}

Intensitas adalah banyaknya/berapa kali seseorang menonton film. Penelitian Becker (1992) dalam Evita (2007) menyebutkan bahwa usia dengan perilaku menonton film berbanding terbalik dengan perilaku menonton televisi. Anak-anak lebih banyak menghabiskan waktunya dengan menonton televisi, dan intensitas menonton televisi terendah pada anak Sekolah Menengah Atas (SMA) dan pada tahun awal kuliah. Sementara intensitas menonton film tertinggi dilakukan anak SMA dan mahasiswa. Kemudian intensitas menonton film menurun kembali pada usia 30 tahun dan terus menurun dengan bertambahnya usia seseorang.

\section{b. Jenis film yang ditonton}

Jenis film adalah kemasan pesan atau format film yang ditonton. Terdapat banyak jenis film yang dapat dipilih oleh khalayak secara bebasa sesuai dengan minat. Filmfilm yang beredar di masyarakat tidak hanya film-film lokal (produksi Indonesia), tetapi banyak juga film yang berasal dari luar negeri seperti film-film produksi Hollywood (Amesika Serikat), Bollywood (India). Hongkong, Jepang, Korea, dan lain-lain. Bahkan produksi film-film asing mendominasi film-film yang beredar di Indonesia, baik dalam tayangan televisi, ditayangkan di bioskop maupun diedarkan dalam bentuk DVD/VCD.

\section{c. Media menonton film}

Film memerlukan media lain untuk dapat ditonton oleh khalayak. Media film dapat berupa proyektor dalam 
gedung bioskop, tayangan televisi, DVD/CD yang diputar melalui DVD/VCD player, komputer/laptop.

\section{d. Akses terhadap film}

Akses terhadap film dibagi menjadi dua yaitu bagaimana cara seseorang mendapatkan film yang ingin ditonton dan ketersediaan sarana dirumah untuk menonton film.

\section{Perilaku Agresi}

Agresi menurut Baron (Koeswara, 1988) adalah tingkah laku yang ditunjukkan untuk melukai dan mencelakakan individu lain yang tidak menginginkan datangnya tingkah laku tersebut. Scheneiders (1955) mengatakan bahwa agresi merupakan luapan emosi sebagai reaksi terhadap kegagalan individu yang ditampakkan dalam bentuk pengrusakan terhadap orang atau benda dengan unsur kesengajaan yang diekspresikan dengan kata-kata (verbal) dan perilaku non verbal. Menurut Abidin (2005) agresi mempunyai beberapa karakteristik. Karakteristik yang pertama, agresi merupakan tingkah laku yang bersifat membahayakan, menyakitkan, dan melukai orang lain. Karakteristik yang kedua, agresi merupakan suatu tingkah laku yang dilakukan oleh seseorang dengan maksud untuk melukai, menyakiti, dan membahayakan orang lain atau dengan sengaja. Karakteristik yang ketiga, agresi tidak hanya dilakukan untuk melukai korban secara fisik, tetapi juga secara psikis. Misalnya melalui kegiatan yang menghina atau menyalahkan. Berdasarkan kesimpulan diatas maka perilaku agresi adalah perilaku/tingkah laku untuk melukai individu lain atau menyakiti individu lain atau pengerusakan benda dengan sengaja baik itu secara verbal, fisik maupun menggunakan alat.

Hanya dengan menonton adegan kekerasan di film saja orang tidak langsung akan menjadi agresi. Menurut Raymond Bavor Little John dalam Valentine (2009) media massa tidak langsung menimbulkan dampak bagi khalayak.

Nyatanya banyak variabel terlibat dalam proses terjadinya efek. Hal ini didukung oleh Klapper yang menyatakan bahwa media massa hanya sebagai "contributing cause". Rakhmat (2005) menyatakan bahwa komunikasi massa terjadi lewat serangkaian perantara. Komunikasi antara lain melalui pengaruh media massa. Untuk sampai kepada perilaku tertentu, maka pengaruh ini diseleksi, disaring, atau bahkan mungkin ditolak sesuai dengan faktor-faktor personal yang mempengaruhi reaksi khalayak, faktor situasional di mana individu berada, dan situasi lingkungan, baik primer (keluarga) atau sekunder (lingkungan masyarakat). Wahyu Widiastuti (2009) melihat perilaku agresi pengaruhi oleh faktor personal dan faktor situasional. Faktor personal memberikan pengaruh terhadap perkembangan perilaku agresif. Jadi dapat dikatakan semakin positif pandangan atau pendapat seseorang terhadap kekerasan dan adegan kekerasan di televisi maka semakin tinggi perilaku agresifnya. Faktor situasional yang mendukung terjadinya tindak kekerasan berpengaruh terhadap perilaku agresif. Hal ini membuktikan bahwa semakin besar iklim permisif dalam lingkungan dan semakin sering tindak kekerasan terjadi di lingkungan maka semakin tinggi kemungkinan terciptanya perilaku agresif. Ada penelitian yang menghasilkan temuan bahwa laki-laki lebih cenderung agresif dibandingkan perempuan. Hasil penelitian Caspi, Elder, dan Bern (1987) dalam Apollo \& Djamaludin A., (2003) menemukan bahwa laki-laki lebih agresif dibandingkan perempuan.

Menurut Koeswara (1998), faktor penyebab remaja berperilaku Agresi bermacam-macam, sehingga dapat dikelompokkan menjadi faktor sosial, faktor lingkungan, faktor situasional, faktor hormon, alkohol, obat-obatan (faktor yang berasal dari luar individu ) dan sifat kepribadian (faktor-faktor yang berasal dari dalam individu), yaitu :

\section{Penyebab sosial}

a. Frustasi, suatu situasi yang menghambat individu dalam usaha mencapai tujuan tertentu yang diinginkannya, dari frustasi maka kan timbul perasaan-perasaan agresi.

b. Provokasi, pelaku agresi provokasi dilihat sebagai ancaman yang harus dihadapi dengan respon agresi untuk meniadakan bahaya yang diisyaratkan oleh ancaman tersebut.

c. Melihat model-model agresi, film dengan kekerasan dapat menimbulkan agresi pada seorang, makin banyak menonton kekerasan, makin besar tingkat agresi mereka terhadap orang lain, makin lama mereka menonton, makin kuat hubungannya tersebut.

2. Penyebab dari lingkungan

a. Polusi udara, bau busuk dan kebisingan dilaporkan dapat menimbulkan perilaku agresi tetapi tidak selalu demikian tergantung dari berbagai faktor lain.

b. Kesesakan (crowding), meningkatkan kemungkinan untuk perilaku agresi terutama bila sering timbul kejengkelan, iritasi, dan frustasi karenanya.

3. Penyebab situasional

a. Bangkitan seksual yaitu film porno yang "ringan" dapat mengurangi tingkat agresi, film porno yang "keras" dapat menambah agresi.

b. Rasa nyeri dapat menimbulkan dorongan agresi yaitu untuk melukai atau mencelakakan orang lain. Dorongan itu kemudian dapat tertuju kepada sasaran apa saja yang ada.

\section{Alkohol dan obat-obatan}

Ada petunjuk bahwa agresi berhubungan dengan kadar alkohol dan obat-obatan. Subyek yang menerima alkohol dalam takara-takaran yang tinggi menunjukkan taraf agresifitas yang lebih tinggi dibandingkan dengan subjek yang tidak menerima alkohol atau menerima alkohol dalam taraf yang rendah. Alkohol dapat melemahkan kendali diri peminumnya, sehingga taraf agresifitas juga tinggi.

\section{Sifat kepribadian}

Menurut Baron (Koeswara, 1988 ) setiap individu akan berbeda dalam cara menentukan dirinya untuk 
mendekati atau menjauhi perilaku agresi. Ada beberapa ynag memiliki sifat karakteristik yang berorientasi untuk menjauhkan diri dari pelanggaranpelanggaran.

Berdasarkan pendapat para ahli diatas maka faktorfaktor yang mempengaruhi perilaku agresi adalah :

a. Faktor personal adalah faktor yang ada di dalam diri individu, yakni usia, jenis kelamin, pendidikan, dan status sosial ekonomi.

b. Faktor situasional adalah faktor yang berada diluar diri individu. Faktor situasional terdiri atas lingkungan keluarga dan lingkungan sosial. Lingkungan sosial terdiri atas lingkungan masyarakat dan pergaulan atau teman.

Menurut Deaux (Priliantini, 2008), ada dua jenis perilaku agresi yaitu:

a. Agresi secara fisik meliputi tingkah laku seperti memukul teman, menarik baju teman dengan kasar, meninju teman, menyikut teman, melempar teman dengan benda, berkelahi, merusak barang milik teman, mengganggu teman, mengancam teman dengan mengacungkan tinju, membuang barang milik teman, mencakar teman, memaksa teman memenuhi keinginannya, melukai diri sendiri.

b. Agresi secara verbal meliputi tingkah laku seperti mengejek teman, menghina teman, mengeluarkan kata-kata kotor, bertengkar mulut, menakut-nakuti teman, memanggil teman dengan nada kasar, mengancam dengan kata-kata mengkritik, menyalahkan, dan menertawakan.

Berdasarkan kesimpulan diatas maka penelitian ini membatasi jenis-jenis bentuk perilaku agresi, yaitu:

a. Agresi verbal/nonfisik meliputi tingkah laku seperti mengejek dan memaki yang menyebabkan lawan bicara tersinggung, emosi marah.

b. Agresi nonverbal/fisik meliputi tingkah laku seperti menampar, memukul, menendang, merusak fasilitas umum (mencoret halte dan tembok pagar).

c. Agresi dengan alat adalah perilaku kekerasan dengan menggunakan alat atau senjata, seperti melempar dengan batu, memukul dengan kayu, menusuk dengan pisau.

\section{Kerangka Pemikiran}

Film merupakan media komunikasi massa. Mulyana (2004) mengatakan bahwa film berpengaruh pada sikap dengan cara memperteguh, menciptakan, dan mengubah norma karena film merupakan cermin atau jendela masyarakat di mana media massa itu berada. Film memerlukan media lain untuk dapat ditonton oleh khalayak. Media Film dapat berupa proyektor dalam gedung bioskop, tayangan televisi, DVD/CD yang diputar melalui DVD/VCD player, komputer, atau laptop dan koneksi internet dengan streaming atau mengunduh melalui situs mengunakan komputer atau laptop. Salah satu jenis film yang dapat berdampak negatif bagi khalayak adalah film yang mengandung adegan kekerasan yang dapat disebut sebagai film kekerasan. Perilaku menonton film kekerasan dipengaruhi oleh intensitas menonton film kekerasan, jenis film kekerasan yang ditonton, media menonton film, dan akses terhadap film. Film tidak langsung mempengaruhi perilaku penonton tetapi kalau berulangkali ditonton dengan intensitas yang tinggi, diduga akan berdampak negatif bagi penonton. Jenis film kekerasan yang ditonton adalah kemasan pesan atau format film kekerasan yang ditonton. Jenis film kekerasan yang banyak ditonton adalah film action/laga, perang, horor, kungfu/silat, thriller, misteri/detektif, atau kriminalitas. Media menonton film adalah sarana yang digunakan seseorang untuk menonton film seperti televisi, DVD/CD player, komputer/ laptop, bioskop, dan akses internet menggunakan komputer atau laptop (di rumah atau di warnet). Akses terhadap film adalah bagaimana cara seseorang mendapatkan film yang ingin ditonton olehnya dan ketersediaan sarana/media menonton film di rumah.

Salah satu dugaan dampak negatif film pada remaja adalah perilaku agresi. Perilaku agresi menurut Baron (Koeswara, 1988) adalah tingkah laku yang ditunjukkan untuk melukai dan mencelakakan individu lain yang tidak menginginkan datangnya tingkah laku tersebut. Perilaku agresif dalam menonton film kekerasan dapat dilihat dari ekspresi ketika marah, reaksi terhadap perilaku agresi dari orang lain, tujuan dia berperilaku agresi, dan perasaan yang muncul setelah berperilaku agresi. Namun hanya dengan menonton adegan kekerasan di film saja orang tidak langsung akan menjadi agresi.

Menurut Raymond Bavor Little John dalam Valentine (2009) media massa tidak langsung menimbulkan dampak bagi khalayak. Nyatanya banyak variabel terlibat dalam proses terjadinya efek. Hal ini didukung oleh Klapper yang menyatakan bahwa media massa hanya sebagai "contributing cause" (Widiastuti, 2009). Rakhmat (2005) menyatakan bahwa komunikasi massa terjadi lewat serangkaian perantara. Komunikasi antara lain melalui pengaruh media massa. Untuk sampai kepada perilaku tertentu, maka pengaruh ini diseleksi, disaring, atau bahkan mungkin ditolak sesuai dengan faktor-faktor personal yang mempengaruhi reaksi khalayak, faktor situasional di mana individu berada, dan situasi lingkungan, baik primer (keluarga) atau sekunder (lingkungan sosial/masyarakat). Dalam penelitian ini faktor personal yang akan diteliti adalah umur, jenis kelamin, pendidikan dan status sosial ekonomi. Faktor personal seperti umur, jenis kelamin, pendidikan, dan status sosial yang diteliti akan menjadi gambaran karakteristik responden sedangkan untuk jenis kelamin akan dilihat hubungannya dengan perilaku agresi.

Faktor situasional yang akan diteliti adalah lingkungan keluarga dan lingkungan sosial. Penelitian di lingkungan keluarga terdiri dari keadaan perilaku agresi yang terjadi dalam keluarga dan hukuman yang diberikan ketika responden berperilaku agresi sedangkan lingkungan sosial yang diteliti terdiri atas keadaan perilaku agresi di sekitar tempat tinggal dan keadaan perilaku agresi dalam pergaulan antar teman. 
Gambar 1. Kerangka Pemikiran Hubungan Perilaku Remaja Menonton Film Kekerasan dengan Perilaku Agresi

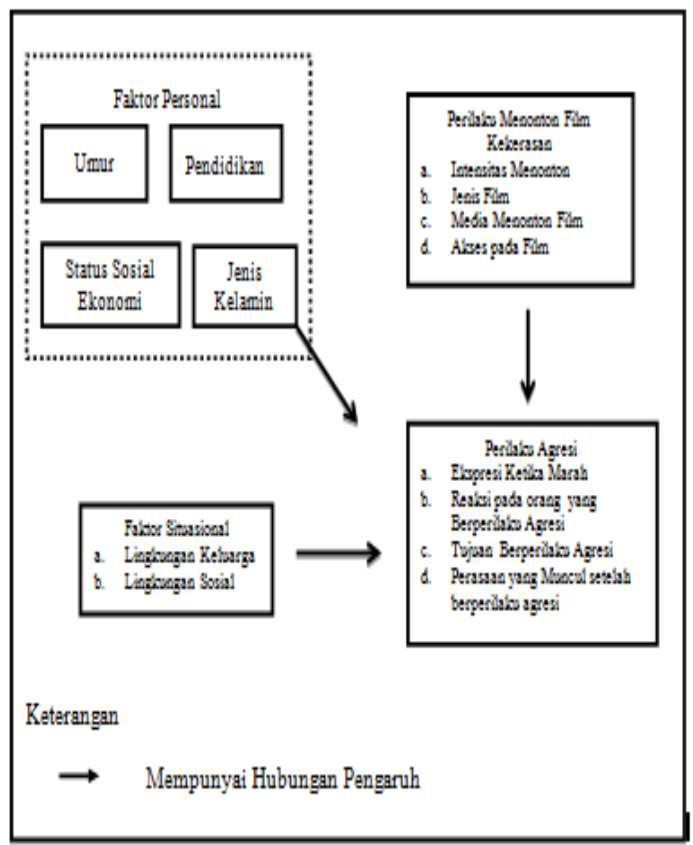

\section{Hipotesis}

Berdasarkan kerangka pemikiran tersebut, dapat disusun hipotesis penelitian adalah

H0: Diduga tidak ada hubungan antara perilaku menonton film kekerasan dengan tingkat perilaku agresi pada remaja.

H1: Diduga ada hubungan antara perilaku menonton film kekerasan dengan tingkat perilaku agresi pada remaja.

\section{PENDEKATAN LAPANGAN}

\section{Lokasi dan Waktu}

Penelitian ini dilakukan pada remaja di SMK Pelita Ciampea (Jl. Raya Warung Borong, Ciampea, Bogor). Pemilihan lokasi ini dipilih secara sengaja (purposive), dengan pertimbangan letak geografis yang tidak terlalu jauh dengan tempat tinggal peneliti, sehingga memudahkan peneliti dalam memperoleh data dan informasi. Penelitian ini dilakukan pada bulan April 2011. Penelitian ini dilakukan dengan menyebarkan kuesioner kepada para responden. Waktu penelitian ditetapkan berdasarkan pertimbangan peneliti.

\section{Teknik Pengumpulan Data}

Penelitian ini dilakukan dengan menggunakan pendekatan penelitian kuantitatif dengan desain survei deskriptif korelasional. Penelitian kuantitatif merupakan penelitian ilmiah yang sistematis terhadap bagian-bagian dan fenomena serta hubungan-hubungannya. Penelitian kuantitatif adalah definisi, pengukuran data, dan statistik objektif melalui perhitungan ilmiah berasal dari sampel orang-orang yang diminta menjawab atas sejumlah pertanyaan yang diberikan oleh peneliti dalam survei. Melalui penelitian survei ini, peneliti mengumpulkan data tertentu dengan memilih sampel dari populasi dengan menggunakan kuesioner. Data Primer diperoleh melalui kuesioner dan wawancara. Kuesioner akan dibagikan kepada responden penelitian, sedangkan wawancara dilakukan kepada informan penelitian. Data sekunder diperoleh dari studi kepustakaan,dan studi dokumentasi.

\section{Teknik Penentuan Responden dan Informan}

Populasi dalam penelitian ini adalah seluruh siswa-siswi di SMK Pelita Ciampea. Sampel dalam penelitian ini adalah seluruh siswa-siswi SMK Pelita Ciampea jurusan pemasaran. Sampel yang dipilih berasal dari jurusan pemasaran karena menurut guru bimbingan konseling (Bu Vita) SMK Pelita Ciampea, siswa- siswi jurusan pemasaran SMK Pelita Ciampea sering terlibat perkelahian. Jumlah responden yang ditentukan untuk penelitian ini sebanyak 45 responden karena sudah memenuhi syarat minimal untuk dijadikan penelitian. Pengambilan sampel dilakukan dengan incidental sampling dengan mendatangi tempat di mana siswa SMK tersebut berkumpul. Incidental sampling adalah cara mengambil responden sebagai sampel berdasarkan kebetulan, yaitu siapa saja yang secara kebetulan bertemu dengan peneliti dapat digunakan sebagai sampel bila orang yang kebetulan ditemui cocok sebagai sumber data (Sugiyono, 2004). Siswa-siswi ditanya, apakah ia merupakan siswa-siswi SMK Pelita Ciampea dan menyukai film-film kekerasan? Jika ya maka siswa-siswi tersebut dijadikan responden. Incidental sampling biasanya dilakukan karena keterbatasan waktu, tenaga, dan dana sehingga tidak dapat mengambil sampel yang besar dan jauh. Keuntungan dari pada teknik ini adalah terletak pada ketepatan peneliti memilih sumber data sesuai dengan variabel yang diteliti (Arikunto, 2002).

\section{Teknik Pengolahan dan Analisis Data}

Data yang terkumpul kemudian akan diolah dengan menggunakan distribusi frekuensi dan tabulasi silang melalui SPSS. Data yang diperoleh bersifat nominal dan ordinal, sehingga untuk menganalisis hubungan antara data tersebut digunakan Chi-Square test. Chi-Square testyakni menguji hipotesis mengenai hubungan antar variabel yang syarat penggunaannya menggunakan variabel nominal sedangkan data ordinal akan diubah menjadi data nominal dengan melakukan pengkategorian melalui skoring. Hasil uji Chi-Square kemudian digunakan untuk melihat keeratan hubungan antara dua variabel dengan rumus koefisien kontingensi (C). Makin besar $\mathrm{C}$ berarti hubungan antar dua variabel makin erat. Nilai C berkisar 0-1.

\section{GAMBARAN UMUM LOKASI PENELITIAN}

SMK Pelita Ciampea terletak di Jl. Raya Warung Borong Desa Benteng Kecamatan Ciampea, Kabupaten Bogor. SMK Pelita Ciampea adalah sekolah yang berada dalam pengelolaan Drs. H.A. Hanapi, M.Pd sebagai pemimpin Yayasan Nurul Walidain T.H. Sekolah ini merupakan sekolah swasta dengan akreditasi A. SMK Pelita Ciampea mempunyai tiga program keahlian yaitu adm. perkantoran, pemasaran,dan akuntansi. SMK Pelita Ciampea dipimpin oleh Dra. Hj. Teti Royati, M.Pd sebagai kepala sekolah. SMK Pelita Ciampea memiliki tiga program keahlian yaitu administrasi perkantoran, perdagangan/pemasaran, dan akuntasi. Pada tahun ajaran 
2010/2011, jumlah siswa SMK Pelita sebanyak 3.122 siswa, jumlah siswa terbanyak berada pada jurusan perdagangan/pemasaran sebanyak 437 siswa. Jumlah siswa laki-laki tebanyak juga berada pada jurusan perdagangan/pemasaran sebanyak 1.081 siswa sedangkan jumlah siswa perempuan terbanyak berada pada jurusan administrasi perkantoran sebanyak 716 siswa. Pekerjaan orangtua siswa yang paling banyak adalah pedagang sebanyak 21 persen dan karyawan swasta 13 persen. Mayoritas penghasilan perbulan orangtua siswa sangat rendah hal ini dapat dilihat dari penghasilan perbulan mayoritas dihasilkan adalah sebesar $\leq \mathrm{Rp} 600.000$ sebanyak 30 persen. Mayoritas pendidikan orang tua siswa adalah SLTA sebesar 13 persen dikuti SLTA sebanyak 11 persen.

SMK Pelita Ciampea memiliki banyak ekstrakurikuler, yakni: Pencak Silat, Taekwondo, Pasus, Pramuka, PEC (Pelita English Club), Rohis, Gatra (Gabungan teater pelita), Basket, Badminton, Futsal, Pelita modeling Club, Taruna Rimbawan. SMK Pelita Ciampea aktif dalam lomba-lomba akademik dan nonakademik, hal ini terlihat dari prestasi-prestasi yang telah diraih SMK ini. Prestasiprestasi berupa juara 1 LKS sekretaris tingkat kabupaten dari tahun 2007-2010, juara 1 debat bahasa inggris tingkat kabupaten dari tahun 2007-2009, dan juara 1 futsal tingkat kabupaten dari tahun 2007-2009.

SMK Pelita Ciampea memiliki kerjasama dengan perusahaan-perusahaan lain untuk menyalurkan lulusan siswa-siswinya, perusahaan-perusahaan yang bekerjasama dengan SMK Pelita Ciampea antara lain: Matahari Departemen Store, PT. Lion Superindo, Giant Botani Square, PT. Hero, Bogor Trade Mall (BTM), Gudang Buku IPB, Toko Buku Salemba, Toko Buku gunung Agung, Ramayana Departemen Store, PT . Antam Tbk., Starmart Yasmin, PD. Darmaga Tani, Koperasi Mitra Karsa, Yonif 315.

Tabel 1. Jumlah Siswa SMK Pelita Ciampea Tahun Ajaran 2010/2011 Menurut Program Keahlian, Kelas, dan Jenis Kelamin

\begin{tabular}{|c|c|c|c|c|c|c|c|c|c|c|}
\hline \multirow{2}{*}{$\begin{array}{l}\text { Program } \\
\text { Keadlian } \\
\end{array}$} & \multicolumn{3}{|c|}{ Kelas 1} & \multicolumn{3}{|c|}{ Kelas 2} & \multicolumn{3}{|c|}{ Kelas 3} & \multirow[t]{2}{*}{ Total } \\
\hline & L & $\mathrm{P}$. & Jumlah & L & $P$ & Jumlah & L & $\mathrm{P}$ & Jumlah & \\
\hline $\begin{array}{l}\text { Adm. } \\
\text { Perkantorann }\end{array}$ & 256 & 330 & 586 & 206 & 175 & 381 & 124 & 211 & 335 & 1302 \\
\hline $\begin{array}{l}\text { Perdaganganl } \\
\text { Pemassaran }\end{array}$ & 305 & 236 & 541 & 196 & 194 & 390 & 235 & 67 & 437 & 1368 \\
\hline Akuntasi & 55 & 143 & 198 & 47 & 86 & 133 & 54 & 67 & 121 & 452 \\
\hline Jumlah & 616 & 709 & 1325 & 499 & 455 & 904 & 413 & 480 & 893 & 3.122 \\
\hline
\end{tabular}

Sumber: Buku Laporan Tahunan SMK Pelita CiampeaTahun Ajarann 201012011

\section{Tata Tertib SMK Pelita Ciampea}

1. Ketertiban

\section{Siswa tidak diperbolehkan}

a. Membuat keributan/ kegaduhan dalam kelas pada saat berlangsungnya pelajaran. Sanksi: diserahkan pada guru yang mengajar saat itu. b. Mengotori/mencoret-coret dan merusak barang milik sekolah. Sanksi: Mengembalikan barang tersebut sesuai kondisi semula.

c. Menghilangkan atau mencuri barang milik sekolah. Sanksi: dipanggil orangtua dan mempertanggungjawabkan perbuatannya.

d. Makan/minum pada saat berlangsungnya pelajaran. Sanksi: diserahkan pada guru yang mengajar saat itu.

e. Membawa/ menghisap rokok di lingkungan dan di luar sekolah pada saat menggunakan seragam sekolah. Sanksi: bila di sekolah rokok dimusnakan dan membersihkan salah satu ruang di sekolah. Bila di luar sekolah ditegur dan dipanggil keesokan harinya oleh kesiswaan.

f. Mencemarkan nama baik sekolah di dalam dan di luar lingkungan sekolah. Sanksi: mengembalikan nama baik sekolah dengan cara lisan maupun tertulis (media massa)

g. Membawa atau menggunakan HP/MP3/MP4/Kamera dan alat elektronik lainnya pada saat KBM berlangsung. Sanksi: alat tersebut disita dan tidak dikembalikan serta pemanggilan orangtua.

2. Kerajinan

Siswa tidak diperbolehkan

a. Datang terlambat

b. Pulang tanpa izin/bolos

c. Keluar kelas pada saat proses belajar mengajar berlangsung tanpa izin

d. Tidak masuk sekolah tanpa surat keterangan orangtua/dokter.

Sanksi: point 1,2,3, dan 4 dilakukan 1-2 kali diserahkan kepada wali kelas/guru piket, jika dilakukan lebih dari 3 kali akan dilakukan pemanggilan orangtua

3. Kerapihan

Siswa tidak diperbolehkan

a. Memakai seragam tidak rapih/tidak dimasukkan

b. Memakai seargam ketat/ rok diatas lutut (putri) atau model tidak sesuai dengan ketentuan sekolah. Sanksi: ukuran dan model seragamnya diperbaiki oleh pihak sekolah atau rok disobek/digunting dan menggunakan mukena.

c. Memakai celana berbentuk corong atau pensil untuk putra. Sanksi: celana disobek/digunting dan menggenakan/memakai sarung.

d. Tidak memakai seragam lengkap (bagde, lokasi, ikat pinggang, kaos dalam, kaos kaki dan seragam sesuai harinya). Sanksi: siswa harus melengkapi seragam.

e. Memakai topi, aksesoris/perhiasan/gelang/kalung/anting bagi 
putra dan ikat pinggang selain warna hitam. Sanksi disita dan menjadi milik sekolah (tidak dikembalikan).

f. Berambut panjang (putra) melampaui batas ketentuan (telinga, alis, dan kerah baju). Sanksi: dipotong/digunting oleh pihak sekolah.

g. Memakai make up berlebihan. Sanksi: dibersihkan oleh siswa.

\section{HASIL-HASIL PENELITIAN}

\section{Gambaran Umum Responden}

\section{Karakteristik Responden}

Individu yang menjadi responden dalam penelitian ini adalah remaja yang berusia 15 sampai 19 tahun, yang dibedakan menjadi dua kategori, yaitu remaja awal (15 sampai 16 tahun) dan remaja akhir (17 sampai 19 tahun).

Tabel 2. Jumlah dan Persentase Responden Berdasarkan Umur dan Jenis Kelamin Responden

\begin{tabular}{|l|c|c|c|c|c|c|}
\hline \multirow{3}{*}{ Umur } & \multicolumn{4}{|c|}{ Jenis Kelamin } & \multicolumn{2}{c|}{ Total } \\
\cline { 2 - 6 } & \multicolumn{2}{|c|}{ Laki-Laki } & \multicolumn{2}{|c|}{ Perempuan } & \multicolumn{2}{c|}{} \\
\cline { 2 - 6 } & $\begin{array}{c}\text { Jumlah } \\
\text { (n) }\end{array}$ & $\begin{array}{c}\text { Persentase } \\
(\%)\end{array}$ & $\begin{array}{c}\text { Jumlah } \\
(\mathrm{n})\end{array}$ & $\begin{array}{c}\text { Persentase } \\
(\%)\end{array}$ & $\begin{array}{c}\text { Jumlah } \\
(\mathrm{n})\end{array}$ & $\begin{array}{c}\text { Persentase } \\
(\%)\end{array}$ \\
\hline $\begin{array}{l}\text { 15-16 } \\
\text { Tahun }\end{array}$ & 10 & 33,3 & 8 & 53,3 & 18 & 40 \\
\hline $\begin{array}{l}17-19 \\
\text { Tahun }\end{array}$ & 20 & 66,7 & 7 & 46,7 & 27 & 60 \\
\hline Total & 30 & 100 & 15 & 100 & 45 & 100 \\
\hline
\end{tabular}

Tabel di atas menunjukkan responden yang berumur 17 sampai 19 tahun (60 persen) cenderung lebih banyak daripada yang berumur 15 sampai 16 tahun (40 persen). Selain itu kebanyakan responden laki-laki berumur 17 sampai 19 tahun $(66,7$ persen) sedangkan pada responden perempuan berumur 15 sampai 16 tahun (53,3 persen). Responden laki-laki umumnya merupakan remaja akhir sedangkan responden perempuan umumnya merupakan remaja awal.

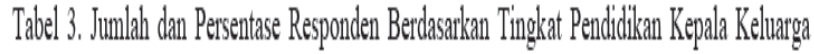 Responden}

\begin{tabular}{|l|c|c|}
\hline Tingkat Pendididikan Kepala Keluarga & Jumlan (n) & Persentase (\%) \\
\hline SDSSMP & 20 & 45,5 \\
\hline SMAPPerguruan Tingog & 25 & 55,5 \\
\hline Total & 45 & 100 \\
\hline
\end{tabular}

Tabel 3 menunjukkan bahwa semua kepala keluarga responden bersekolah. Tingkat pendidikan kepala keluarga responden lebih banyak berpendidikan tinggi (SMA/Perguruan Tinggi) sebesar 55,5 persen daripada responden berpendidikan rendah (SD/SMP) sebesar 45,5 persen.
Tabel 4. Jumlah dan Persentase Responden Berdasarkan Jenis Pekerjaan Kepala Keluarga Responden

\begin{tabular}{|l|c|c|}
\hline \multicolumn{1}{|c|}{ Jenis Pekerjaan Kepala Keluarga } & Jumlah (n) & Persentase (\%) \\
\hline Buruh & 5 & 11,1 \\
\hline Wiraswasta (Pengusaha dan pedagang) & 23 & 51,1 \\
\hline Pegawai kantor (Pemerintah dan Swasta) & 17 & 37,7 \\
\hline Total & 45 & 100 \\
\hline
\end{tabular}

Tabel di atas menunjukkan jenis pekerjaan yang dilakukan oleh kepala keluarga responden lebih banyak sebagai pengusaha dan pedagang sebesar 51,1 persen. Kepala keluarga responden yang berasal dari sektor formal yaitu pegawai swasta dan pemerintah juga cukup tinggi yaitu sebesar 37,7 persen.

Berdasarkan tabel 2 dan tabel 3 dapat disimpulkan umumnya kepala keluarga berpendidikan tinggi dengan persentase 55 persen dan memiliki jenis pekerjan yang umumnya sebagai wiraswasta dengan persentase 51,1 persen sehingga dapat disimpulkan bahwa responden cenderung berasal dari keluarga golongan menengah.

\section{Faktor Situasional}

Responden yang berada dalam pengasuhan orangtua diduga memiliki hubungan pengaruh dalam perilaku responden sehari-hari. Pengaruh dapat melalui keadaan lingkungan keluarga dan sanksi/hukuman ketika berperilaku agresi. Selain lingkungan keluarga, perilaku responden diduga memiliki hubungan pengaruh dengan lingkungan tempat tinggal dan teman sepergaulan. Lingkungan keluarga dan lingkungan sosial merupakan bagian dari faktor situasional yang diduga mempengaruhi perilaku responden. Hasil analisis tersebut dapat dilihat pada tabel 5 sampai tabel 10 .

1. Lingkungan keluarga

a. Perilaku agresi di lingkungan keluarga

Tabel 5. Jumlah dan Persentase Responden Berdasarkan Intensitas Perilaku Agresi di Lingkungan Keluarga

\begin{tabular}{|l|c|c|c|c|c|c|}
\hline \multirow{3}{*}{$\begin{array}{c}\text { Intensitas Perilaku Agresi di } \\
\text { Lingkungan Keluarga }\end{array}$} & \multicolumn{4}{|c|}{ Jenis Kelamin } & \multicolumn{3}{c|}{ Total } \\
\cline { 2 - 7 } & $\begin{array}{c}\text { Laki- } \\
\text { Laki }\end{array}$ & \multicolumn{2}{|l|}{ Perempuan } & \multicolumn{4}{c|}{} \\
\cline { 2 - 7 } & n & $\%$ & n & $\%$ & n & $\%$ \\
\hline Tidak Pernah & 7 & 23,3 & 2 & 13,3 & 9 & 20 \\
\hline Jarang & 19 & 63,3 & 13 & 86,7 & 32 & 71,1 \\
\hline Sering & 4 & 13,3 & 0 & 0 & 4 & 8,9 \\
\hline Total & 30 & 100 & 15 & 100 & 45 & 100 \\
\hline
\end{tabular}

Pada tabel di atas terlihat persentase intensitas perilaku agresi di lingkungan keluarga lebih banyak dengan intensitas jarang terjadi sebesar 71,1 persen, tetapi persentase intensitas perilaku agresi di lingkungan keluarga yang pernah melakukan perilaku agresi sebanyak 80 persen. Intensitas sering hanya terjadi pada responden laki-laki sebesar 13,3 persen.

b. Hukuman yang diberikan orangtua ketika berperilaku agresi 
Tabel 6. Jumlah dan Persentase Responden Berdasarkan Jenis Hukuman yang diterima Responden dari Orangtua

\begin{tabular}{|l|c|c|c|c|c|c|}
\hline \multirow{2}{*}{ Jenis Hukuman } & \multicolumn{4}{|c|}{ Jenis Kelamin } & \multicolumn{2}{c|}{ Total } \\
\cline { 2 - 6 } & Laki-Laki & \multicolumn{2}{|c|}{ Perempuan } & \multicolumn{2}{c|}{} \\
\cline { 2 - 6 } & n & $\%$ & n & $\%$ & n & $\%$ \\
\hline $\begin{array}{l}\text { DilaranngKeluar } \\
\text { Rumah }\end{array}$ & 9 & 30 & 5 & 33,3 & 14 & 31,1 \\
\hline Makian/Teguran & 30 & 100 & 14 & 93,3 & 44 & 97,8 \\
\hline Dipukul & 6 & 20 & 0 & 0 & 6 & 13,3 \\
\hline
\end{tabular}

Dari tabel di atas dapat dilihat persentase jenis hukuman terbanyak adalah makian/teguran sebesar 97,8 persen dari seluruh total responden. Jenis hukuman yang diterima responden dapat lebih dari satu jenis. Persentase dipukul hanya diterima responden laki-laki sebesar 13,3 persen dari seluruh total responden sedangkan perempuan tidak mendapatkan hukuman dipukul. Hal ini menunjukkan hukuman yang diterima responden laki-laki lebih keras dan bersifat agresif dibandingkan responden perempuan.

c. Ikhtisar hubungan antara lingkungan keluarga dengan jenis kelamin

Tabel 7. Jumlah dan Persentase Responden Berdasarkan Perilaku Agresi di Lingkungan Keluarga

\begin{tabular}{|c|c|c|c|c|c|c|}
\hline \multirow{3}{*}{$\begin{array}{l}\text { Perilaku Agresi } \\
\text { di Lingkungan } \\
\text { Keluarga }\end{array}$} & \multicolumn{4}{|c|}{ Jenis Kelamin } & \multirow{2}{*}{\multicolumn{2}{|c|}{ Total }} \\
\hline & \multicolumn{2}{|c|}{ Laki-Laki } & \multicolumn{2}{|c|}{ Peremplan } & & \\
\hline & n & $\%$ & n & $\%$ & n & $\%$ \\
\hline Rendah & 8 & 26,7 & 5 & 33,3 & 13 & 28,9 \\
\hline Tinggi & 22 & 73,3 & 10 & 66,7 & 32 & 71,1 \\
\hline Total & 30 & 100 & 15 & 100 & 45 & 100 \\
\hline
\end{tabular}

Berdasarkan tabel 7 dapat dilihat umumnya perilaku agresi di lingkungan keluarga responden dengan intensitas tinggi sebesar 71,1 persen. Intensitas perilaku agresi di lingkungan keluarga responden laki-laki cenderung lebih tinggi $(73,3$ persen) dibandingkan dengan responden perempuan (66,7 persen).

2. Lingkungan sosial

a. Perilaku agresi di lingkungan tempat tinggal

Tabel 8. Jumlah dan Persentase Responden Berdasarkan Intensitas Perilaku Agresi di Lingkungan Tempat Tinggal Responden

\begin{tabular}{|l|c|c|c|c|c|c|}
\hline Intensitas Perilaku & \multicolumn{4}{|c|}{ Jenis Kelamin } & \multicolumn{3}{|c|}{ Total } \\
\cline { 2 - 7 } Agresi di Lingkungan & Laki-Laki & \multicolumn{2}{|c|}{ Perempuan } & \multicolumn{2}{c|}{} \\
\cline { 2 - 7 } Tempat Tinggal & $\mathrm{n}$ & $\%$ & $\mathrm{n}$ & $\%$ & $\mathrm{n}$ & $\%$ \\
\hline Tidak Pernah & 6 & 20 & 2 & 13,3 & 8 & 17,8 \\
\hline Jarang & 21 & 70 & 13 & 86,7 & 34 & 75,6 \\
\hline Sering & 3 & 10 & 0 & 0 & 3 & 6,7 \\
\hline Total & 30 & 100 & 15 & 100 & 45 & 100 \\
\hline
\end{tabular}

Pada tabel 8 menunjukkan perilaku agresi yang terjadi di lingkungan tempat tinggal responden umumnya jarang terjadi (75,6 persen). Responden yang melaporkan sering terjadi perilaku agresi di tempat tinggal hanya 10 persen pada responden laki-laki. Maka secara keseluruhan ada 82,3 persen dari responden yang melaporkan ada perilaku agresi di lingkungan tempat tinggal responden namun lebih cenderung jarang daripada sering.

b. Perilaku agresi oleh teman

Tabel 9. Jumlah dan Persentase Responden Berdasarkan Perilaku Agresi yang Ditampilkan Teman Responden

\begin{tabular}{|l|c|c|c|c|c|c|}
\hline \multirow{2}{*}{$\begin{array}{c}\text { Perilaku Agresi } \\
\text { oleh Teman }\end{array}$} & \multicolumn{4}{|c|}{ Jenis Kelamin } & \multicolumn{2}{|c|}{ Total } \\
\cline { 2 - 7 } & Laki-Laki & \multicolumn{2}{|c|}{ Perempuan } & \multicolumn{2}{|c|}{} \\
\cline { 2 - 7 } & $\mathrm{n}$ & $\%$ & $\mathrm{n}$ & $\%$ & $\mathrm{n}$ & $\%$ \\
\hline Tidak Pernah & 3 & 10 & 3 & 20 & 6 & 13,3 \\
\hline Jarang & 17 & 56,7 & 11 & 73,3 & 28 & 62,2 \\
\hline Sering & 10 & 33,3 & 1 & 6,7 & 11 & 24,4 \\
\hline Total & 30 & 100 & 15 & 100 & 45 & 100 \\
\hline
\end{tabular}

Tabel di atas menunjukan laporan responden terhadap perilaku agresi yang dilakukan teman umumnya dengan intensitas jarang (62,2 persen). Intensitas sering lebih banyak terjadi pada responden laki-laki (33,3 persen) dibandingkan perempuan $(6,7$ persen). Maka secara keseluruhan ada 86,6 persen dari responden yang melaporkan ada perilaku agresi yang dilakukan oleh teman. Perilaku yang dilakukan di lingkungan teman (24,4 persen) lebih tinggi dibandingkan dengan perilaku yang dilakukan di lingkungan keluarga (8,9 persen) dan lingkungan tempat tinggal $(6,7$ persen). Bila dilihat dari perkembangan remaja dengan umur 15-19 tahun (laki-laki) lebih dipengaruhi oleh lingkungan teman. Remaja laki-laki yang melakukan berperilaku agresi lebih disebabkan ia salah memilih teman yaitu memilih teman yang berperilaku agresi dibandingkan dari faktor lingkungan keluarga.

c. Ikhtisar hubungan antara lingkungan sosial dengan jenis kelamin

Tabel 10. Jumlah dan Persentase Responden Berdasarkan Perilaku Agresi di Lingkungan Sosial dengan Jenis Kelamin

\begin{tabular}{|c|c|c|c|c|c|c|}
\hline \multirow{3}{*}{$\begin{array}{c}\text { Perilaku Agresi } \\
\text { di Lingkungan } \\
\text { Sosial }\end{array}$} & \multicolumn{4}{|c|}{ Jenis Kelamin } & \multicolumn{2}{|c|}{ Total } \\
\hline & \multicolumn{2}{|c|}{ Laki-Laki } & \multicolumn{2}{|c|}{ Perempuan } & & \\
\hline & n & $\%$ & n & $\%$ & n & $\%$ \\
\hline Rendah & 6 & 20 & 4 & 26,7 & 10 & 22,2 \\
\hline Tinggi & 24 & 80 & 11 & 73,3 & 35 & 77,8 \\
\hline Total & 30 & 100 & 15 & 100 & 45 & 100 \\
\hline
\end{tabular}

Berdasarkan tabel 10 terlihat umumnya perilaku agresi di lingkungan sosial terjadi dengan intensitas tinggi sebesar 77,8 persen. Umumnya perilaku agresi di lingkungan sosial dengan intensitas tinggi lebih banyak terjadi pada 
responden laki-laki (80 persen) dibandingkan responden perempuan (73,3 persen).

\section{Perilaku Remaja Menonton Film Kekerasan}

Salah satu jenis film yang dapat berdampak negatif bagi khalayak adalah film yang mengandung adegan kekerasan yang dapat disebut sebagai film kekerasan. Perilaku menonton film kekerasan dipengaruhi oleh intensitas menonton film kekerasan, jenis film kekerasan yang ditonton, media menonton film, dan akses terhadap film.

1. Intensitas menonton film kekerasan

Intensitas menonton film kekerasan adalah banyaknya seseorang menonton film kekerasan. Film kekerasan tidak langsung mempengaruhi perilaku penonton tetapi kalau berulangkali ditonton dengan intensitas yang tinggi, diduga akan berdampak negatif bagi penonton. Dalam penelitian ini intensitas menonton film kekerasan dibagi menjadi intensitas jarang dan sering. Diduga semakin sering responden menonton film kekerasan semakin tinggi perilaku agresi yang ditampilkan.

Tabel 11. Jumlah dan Persentase Responden Berdasarkan Intensitas Perilaku Menonton Film Kekerasan

\begin{tabular}{|l|c|c|c|c|c|c|}
\hline Intensitas Perilaku & \multicolumn{4}{|c|}{ Jenis Kelamin } & \multicolumn{3}{c|}{ Total } \\
\cline { 2 - 7 } $\begin{array}{c}\text { Menonton Film } \\
\text { Kekerasan }\end{array}$ & Laki-Laki & \multicolumn{2}{|c|}{ Perempuan } & \multicolumn{2}{c|}{} \\
\cline { 2 - 7 } \multicolumn{1}{c|}{} & n & $\%$ & n & $\%$ & n & $\%$ \\
\hline Jarang & 20 & 66,7 & 8 & 53,3 & 28 & 62,2 \\
\hline Sering & 10 & 33,3 & 7 & 46,7 & 17 & 37,8 \\
\hline Total & 30 & 100 & 15 & 100 & 45 & 100 \\
\hline
\end{tabular}

Berdasarkan tabel 11 terlihat intensitas responden dalam menonton film kekerasan umumnya adalah intensitas jarang sebesar 62,2 persen daripada intensitas sering sebesar 37,8 persen. Intensitas sering lebih banyak terjadi pada responden wanita sebesar 46,7 persen dibandingkan laki-laki sebesar 33,3 persen sedangkan pada intensitas jarang cenderung lebih banyak responden laki-laki $(66,7$ persen) daripada responden perempuan (53,3 persen).

2. Jenis film kekerasan yang ditonton

Jenis film kekerasan yang ditonton adalah kemasan pesan atau format film kekerasan yang ditonton. Jenis film kekerasan yang diteliti adalah film action/laga, perang, horor, kungfu/silat, thriller, misteri/detektif, atau kriminalitas. Diduga bahwa semakin banyak jenis film kekerasan yang ditonton, semakin tinggi perilaku agresi yang akan dilakukan.
Tabel 12. Jumlah dan Persentase Responden Berdasarkan Jenis Film Kekerasan yang Ditonton Responden

\begin{tabular}{|l|c|c|c|c|c|c|}
\hline \multirow{3}{*}{\begin{tabular}{c}
\multirow{3}{*}{ Jenis Film } \\
Kekerasan
\end{tabular}} & \multicolumn{4}{|c|}{ Jenis Kelamin } & \multicolumn{2}{c|}{ Total } \\
\cline { 2 - 6 } & Laki-Laki & \multicolumn{2}{c|}{ Perempuran } & \multicolumn{2}{c|}{} \\
\cline { 2 - 6 } & $\mathrm{n}$ & $\%$ & $\mathrm{n}$ & $\%$ & $\mathrm{n}$ & $\%$ \\
\hline Film Action/Laga & 23 & 76,7 & 7 & 46,7 & 30 & 66,7 \\
\hline Film Perang & 22 & 73,3 & 2 & 13,3 & 24 & 53,3 \\
\hline Film Horor & 24 & 80 & 10 & 66,7 & 34 & 75,6 \\
\hline Film Kungfu/Silat & 18 & 60 & 0 & 0 & 18 & 40 \\
\hline Film Thriller & 4 & 13,3 & 1 & 6,7 & 5 & 11,1 \\
\hline $\begin{array}{l}\text { Film } \\
\text { Misteri/Detektif }\end{array}$ & 6 & 20 & 8 & 53,3 & 14 & 31,1 \\
\hline Film Kriminalitas & 5 & 16,7 & 0 & 0 & 5 & 11,1 \\
\hline
\end{tabular}

Tabel 12 menunjukkan persentase film kekerasan yang cenderung sering ditonton responden adalah film horor sebanyak 75,6 persen. Umumnya responden laki-laki lebih memilih film action/laga sebesar 76,7 persen, film perang sebesar 73,3 persen, dan film horor sebesar 80 persen sedangkan responden perempuan cenderung lebih memilih film horor sebesar 66,7 persen. Walaupun responden laki-laki cenderung menonton film kekerasan dengan intensitas jarang tetapi pilihan jenis menonton film kekerasan adalah film action/laga, dan perang lebih banyak mengandung adegan kekerasan dan lebih sadis daripada responden perempuan yang menonton film dengan intensitas sering tapi hanya cenderung menonton film horor dengan tingkat perilaku agresinya lebih rendah dibandingkan film action/laga dan perang.

3. Media film yang digunakan

Media menonton film kekerasan adalah jenis media yang digunakan untuk menonton film kekerasan. Media menonton film merupakan jenis sarana yang biasa digunakan untuk menonton film kekerasan. Film memerlukan media lain untuk dapat ditonton oleh khalayak. Media film dapat berupa proyektor dalam gedung bioskop, tayangan televisi, DVD/CD yang diputar melalui DVD/VCD player, komputer/laptop.

Tabel 13. Jumlah dan Persentase Responden Berdasarkan Media Film yang Digunakan

\begin{tabular}{|l|c|c|}
\hline \multicolumn{1}{|c|}{ Media Film yang Digunakan } & Jumlah $(\mathrm{n})$ & Persentase $(\%)$ \\
\hline Televisi & 44 & 97,8 \\
\hline DVD Player & 39 & 86,7 \\
\hline Komputer'Laptop & 9 & 20 \\
\hline Bioskop & 10 & 22,2 \\
\hline Lainnya & 1 & 2,2 \\
\hline
\end{tabular}

Tabel 13 menunjukkan media yang umumnya sering digunakan adalah televisi dan DVD player sebanyak 97,8 persen dan 86,7 persen. Televisi dan DVD player bukan merupakan barang mewah lagi, hampir setiap responden mempunyai televisi dan DVD player dirumahnya. Media lainnya yang digunakan adalah handphone sebanyak 2,2 persen. Handphone yang digunakan terdapat tv tuner sehingga dapat menonton acara televisi di handphone. 
4. Akses terhadap film

Akses terhadap film dibagi menjadi dua yaitu bagaimana cara seseorang mendapatkan film yang ingin ditonton dan ketersediaan sarana di rumah untuk menonton film.

a. Cara mendapatkan film

Tabel 14. Jumlah dan Persentase Responden Berdasarkan Cara Mendapatkan Film

\begin{tabular}{|l|c|c|}
\hline $\begin{array}{c}\text { Cara Responden Mendapatkan } \\
\text { Film }\end{array}$ & Jumlah(n) & Persentase (\%) \\
\hline Menyewa & 9 & 20 \\
\hline Membeli & 33 & 73,3 \\
\hline Mencopy/Meminjam dari Teman & 20 & 44,4 \\
\hline Menonton di Tempat Teman & 16 & 35,6 \\
\hline Mendowload dari Situs Tertentu & 8 & 17,8 \\
\hline Lainnya & 4 & 8,9 \\
\hline
\end{tabular}

Tabel di atas menunjukkan bahwa umumnya responden remaja mendapatkan film kekerasan dengan cara membelinya. Hal ini disebabkan murah dan mudahnya DVD bajakan yang diperjualbelikan. Harga DVD bajakan yang diperjualbelikan berkisar Rp5000 sampai Rp7000 perkeping. Tempat menjual DVD bajakan mudah ditemui di dekat sekolah maupun di sekitar pasar.

b. Sarana yang dimiliki di rumah untuk menonton film

Tabel 15. Jumlah dan Persentase Responden Berdasarkan Sarana yang Dimilikidi Rumah Untuk Menonton Film Kekerasan

\begin{tabular}{|l|c|c|}
\hline $\begin{array}{c}\text { Sarana yang Dimiliki Responden di } \\
\text { Rumah Untuk Menonton Film } \\
\text { Kekerasan }\end{array}$ & Jumlah(n) & $\begin{array}{c}\text { Persentase } \\
(\%)\end{array}$ \\
\hline Televisi & 44 & 97,8 \\
\hline DVD Player & 41 & 91,1 \\
\hline Komputer/Laptop & 8 & 17,8 \\
\hline
\end{tabular}

Pada tabel 15 menunjukkan kecenderungan responden remaja yang memiliki sarana televisi dan DVD player sebanyak 97,8 persen dan 91,1 persen. Hal ini dikarenakan televisi dan DVD player bukan merupakan barang mewah lagi. umumnya responden memilki televisi dan DVD player di rumahnya.

5. Ikhtisar hubungan antara perilaku menonton film kekerasan dengan jenis kelamin
Tabel 16. Jumlah dan Persentase Perilaku Menonton Film Kekerasan dengan Jenis Kelamin

\begin{tabular}{|l|c|c|c|c|c|c|}
\hline \multirow{2}{*}{$\begin{array}{c}\text { Perilaku } \\
\text { Menonton Film }\end{array}$} & \multicolumn{4}{|c|}{ Jenis Kelamin } & \multicolumn{3}{c|}{ Total } \\
\cline { 2 - 6 } \begin{tabular}{l} 
Kekerasan \\
\cline { 2 - 7 } \cline { 2 - 6 }
\end{tabular} & Laki-Laki & \multicolumn{2}{|c|}{ Perempuan } & \multicolumn{2}{c}{} \\
\hline $\begin{array}{l}\text { Intensitas } \\
\text { Rendah }\end{array}$ & 14 & 46,7 & 6 & 40 & 20 & 44,4 \\
\hline Intensitas Tinggi & 16 & 53,3 & 9 & 60 & 25 & 55,6 \\
\hline Total & 30 & 100 & 15 & 100 & 45 & 100 \\
\hline
\end{tabular}

Tabel di atas memperlihatkan umumnya responden perempuan menonton film kekerasan dengan intensitas tinggi (60 persen) lebih banyak dibandingkan responden laki-laki (53,3 persen) sedangkan dengan intensitas rendah responden lakilaki lebih banyak (46,7 persen) dibandingkan responden perempuan (40 persen). Keseluruhan responden cenderung berperilaku menonton film kekerasan dengan intensitas tinggi sebanyak 55,6 persen.

\section{Perilaku Agresi Remaja}

Salah satu dugaan dampak negatif film pada remaja adalah perilaku agresi. Perilaku agresi menurut Baron (Koeswara, 1988) adalah tingkah laku yang ditunjukkan untuk melukai dan mencelakakan individu lain yang tidak menginginkan datangnya tingkah laku tersebut. Perilaku agresif dalam menonton film kekerasan dapat dilihat dari ekspresi ketika marah, reaksi terhadap perilaku agresi dari orang lain, tujuan dia berperilaku agresi, dan perasaan yang muncul setelah berperilaku agresi.

\section{Cara Responden Mengekspresikan Perilaku Agresi}

Tabel 17. Jumlah dan Persentase Responden Berdasarkan Cara Mengekspresikan Perilaku Agresi

\begin{tabular}{|l|c|c|c|c|c|c|}
\hline \multirow{2}{*}{ Perilaku Agresi } & \multicolumn{4}{|c|}{ Jenis Kelamin } & \multicolumn{3}{c|}{ Total } \\
\cline { 2 - 6 } & \multicolumn{2}{|c|}{ Laki-Laki } & \multicolumn{2}{c|}{ Perempuan } & \multicolumn{2}{c|}{} \\
\cline { 2 - 6 } & $\mathrm{n}$ & $\%$ & $\mathrm{n}$ & $\%$ & $\mathrm{n}$ & $\%$ \\
\hline Mengejek & 21 & 70 & 13 & 86,7 & 34 & 75,6 \\
\hline Memaki & 17 & 56,7 & 8 & 53,3 & 25 & 55,6 \\
\hline Menampar & 9 & 30 & 6 & 40 & 15 & 33,3 \\
\hline Memukul & 16 & 53,3 & 1 & 6,7 & 17 & 37,8 \\
\hline Menendang & 8 & 26,7 & 0 & 0 & 8 & 17.8 \\
\hline $\begin{array}{l}\text { Merusak Fasilitas } \\
\text { Umum }\end{array}$ & 6 & 20 & 1 & 6,7 & 7 & 15,6 \\
\hline $\begin{array}{l}\text { Melempar Dengan } \\
\text { Batu }\end{array}$ & 2 & 6,7 & 0 & 0 & 2 & 4,4 \\
\hline $\begin{array}{l}\text { Memukul Dengan } \\
\text { Kayu }\end{array}$ & 1 & 3,3 & 0 & 0 & 1 & 2,2 \\
\hline
\end{tabular}

Tabel 17 menunjukkan bahwa umumnya keterlibatan perilaku agresi yang ditunjukkan adalah perilaku agresi verbal seperti mengejek dan memaki sebanyak 93,3 persen dan 75,6 persen. Responden laki-laki memiliki intesitas perilaku agresi lebih tinggi dibandingkan responden perempuan yang terlihat pada tabel di atas. Responden perempuan cenderung mengekspresikan perilaku agresi verbal seperti mengejek dan memaki sebesar 86,7 persen dan 53,3 persen. Responden laki-laki cenderung mengekspresikan perilaku agresi verbal dan perilaku 
agresi fisik. Perilaku agresi verbal yang cenderung responden laki-laki ekspresikan adalah perilaku mengejek sebesar 70 persen.Perilaku agresi fisik yang dilakukan responden laki-laki cenderung memukul (53,3 persen) daripada menampar (30 persen) dan menendang (26,7 persen) sedangkan responden perempuan cenderung melakukan perilaku agresi fisik menampar (40 persen) daripada memukul (6,7 persen). Responden juga melakukan perilaku agresi merusak fasilitas umum sebesar 20 persen untuk responden laki-laki dan 6,7 persen untuk responden perempuan. Perilaku agresi dengan menggunakan alat hanya terjadi pada responden laki-laki (10 persen) daripada respondenperempuan yang tidak sama sekali.

2. Cara Responden Mengeskpresikan Perilaku Agresi Kepada Orang di Sekitarnya

Tabel 18. Jumlah dan Persentase Responden Laki-Laki Berdasarkan Cara Mengeskpresikan Perilaku Agresi Kepada Orang di Sekitarnya

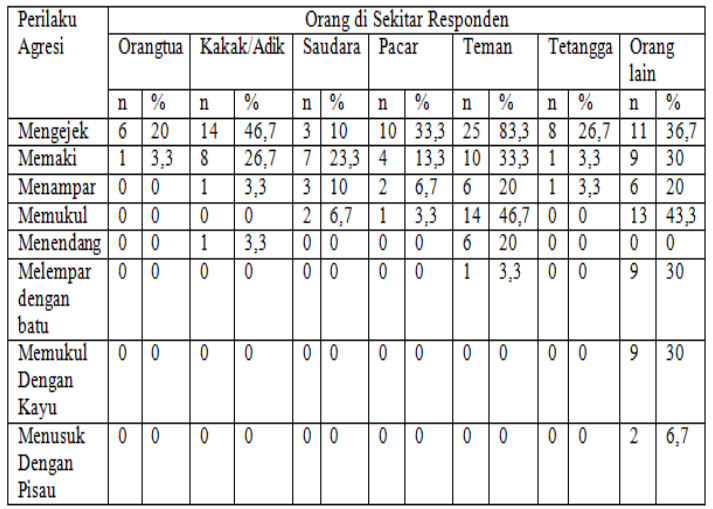

Tabel 18 menunjukkan responden laki-laki cenderung melakukan perilaku agresi mengejek pada teman (83,3 persen), memaki pada teman $(33,3$ persen), memukul pada teman (46,7 persen), menampar dan menendang pada teman (20 persen) sedangkan melempar batu dan memukul dengan kayu pada orang lain (30 persen) lalu menusuk pisau pada orang lain (6,7 persen). Hal ini menunjukkan responden laki-laki cenderung berperilaku lebih agresi pada orang lain. Pada orangtua responden laki-laki cenderung melakukan perilaku agresi verbal seperti mengejek (20 persen) dan memaki (3,3 persen) tapi kepada pacar perilaku agresi lebih keras mengejek dan memaki bahkan sampai menampar juga. Responden laki-laki cenderung melakukan perilaku agresi bersifat lebih kejam terhadap teman dan orang lain.

Tabel 19. Jumlah dan Persentasi Responten Perempuan Berdasarkan Cara Mengeskpresikan Perilaku Agresi Kepada Orang di Sekitarnya

\begin{tabular}{|c|c|c|c|c|c|c|c|c|c|c|c|c|c|c|}
\hline \multirow{3}{*}{$\begin{array}{l}\text { Perilaku } \\
\text { Agresi }\end{array}$} & \multicolumn{14}{|c|}{ Orang di Sekitar Responden } \\
\hline & \multicolumn{2}{|c|}{ Orangtua } & \multicolumn{2}{|c|}{ Kakak/Adik } & \multicolumn{2}{|c|}{ Saudara } & \multicolumn{2}{|c|}{ Pacar } & \multicolumn{2}{|c|}{ Teman } & \multicolumn{2}{|c|}{ Tetangga } & \multicolumn{2}{|c|}{$\begin{array}{l}\text { Orang } \\
\text { lain }\end{array}$} \\
\hline & n & $\%$ & n & $\%$ & & $\%$ & II & $\%$ & & $\%$ & & $\%$ & & $\%$ \\
\hline Mengejek & 4 & 26,7 & 5 & 33,3 & 2 & 13,3 & 3 & 20 & 8 & 53,3 & 3 & 20 & 1 & 6,7 \\
\hline Memaki & o & 0 & & 20 & & 6,7 & 2 & 13,3 & 3 & 20 & 0 & 0 & 3 & 20 \\
\hline Menampar & 0 & 0 & & 0 & 1 & 6,7 & 3 & 20 & 4 & 26,7 & 1 & 6,7 & 0 & 0 \\
\hline Memukul & 0 & 0 & & 6,7 & 0 & 0 & 0 & 0 & 2 & 13,3 & 0 & 0 & 0 & 0 \\
\hline Menendang & 0 & 0 & 0 & 0 & 0 & 0 & 1 & 6,7 & & 0 & 0 & 0 & & 0 \\
\hline
\end{tabular}

Tabel di atas menujukkan responden perempuan melakukan perilaku agresi umumnya kepada sesama teman. Perilaku agresi yang paling sering ditunjukkan adalah mengejek teman sebanyak 53,3 persen dan memaki pada teman dan tetangga (20 persen). Perilaku agresi fisik juga ditunjukkan responden perempuan. Umumnya perilaku agresi fisik yang ditunjukkan adalah menampar teman (26,7 persen), memukul kakak/adik (6,7 persen), dan menendang pacar (6,7 persen).

3. Reaksi Ketika Ada yang Berperilaku Agresi

Tabel 20. Jumlah dan Persentase Responden Berdasarkan Reaksi Ketika Ada yang Berperilaku Agresi

\begin{tabular}{|l|c|c|c|c|c|c|}
\hline \multirow{3}{*}{\begin{tabular}{c} 
Reaksi Ketika Ada yang \\
\multirow{2}{*}{ Berperilaku Agresi }
\end{tabular}} & \multicolumn{4}{|c|}{ Jenis Kelamin } & \multicolumn{2}{c|}{ Total } \\
\cline { 2 - 7 } & Laki-Laki & \multicolumn{2}{c|}{ Peremplan } & \multicolumn{2}{c|}{} \\
\cline { 2 - 7 } & n & $\%$ & n & $\%$ & n & $\%$ \\
\hline $\begin{array}{l}\text { Mengalah/Tidak Mau Mencari } \\
\text { Keributan }\end{array}$ & 5 & 16,7 & 7 & 46,7 & 12 & 26,7 \\
\hline Bertahan/Melindungi Diri & 17 & 56,7 & 3 & 20 & 20 & 44,4 \\
\hline Menyerang Balas Mengganggu & 7 & 23,3 & 5 & 33,3 & 12 & 26,7 \\
\hline Mencari Pertolongan & 1 & 3,3 & 0 & 0 & 1 & 2,2 \\
\hline Total & 30 & 100 & 15 & 100 & 45 & 100 \\
\hline
\end{tabular}

Tabel 20 menunjukkan umumnya reaksi responden ketika ada yang berperilaku agresi adalah bertahan atau melindungi diri (44,4 persen). Responden lakilaki cenderung memilih bertahan dan melindungi diri ketika ada yang berperilaku agresi kepadanya (56,7 persen) sedangkan responden perempuan lebih memilih mengalah atau tidak mencari keributan (46,7 persen) namun lebih banyak responden perempuan yang akan menyerang/balas menganggu ketika ada yang berperilaku agresi (33,3 persen) dibandingkan dengan responden laki-laki (23,3 persen) dan tidak ada responden perempuan yang mencari pertolongan ketika ada yang berperilaku agresi dibandingkan dengan responden laki-laki (3,3 persen).

\section{Tujuan Reponden Berperilaku Agresi}

Tabel 21. Jumlah dan Persentase Responden Berdasarkan Tujuan Responden Berperilaku Agresi

\begin{tabular}{|l|c|c|c|c|c|c|}
\hline \multirow{2}{*}{$\begin{array}{l}\text { Tujuan Berperilaku } \\
\text { Agresi }\end{array}$} & \multicolumn{4}{|c|}{ Jenis Kelamin } & \multicolumn{2}{c|}{ Total } \\
\cline { 2 - 7 } & Laki-Laki & \multicolumn{2}{|c|}{ Perempuan } & \multicolumn{2}{c|}{} \\
\cline { 2 - 7 } & $\mathrm{n}$ & $\%$ & $\mathrm{n}$ & $\%$ & $\mathrm{n}$ & $\%$ \\
\hline $\begin{array}{l}\text { Membela Diri atau } \\
\text { Teman }\end{array}$ & 17 & 56,7 & 7 & 46,7 & 24 & 53,3 \\
\hline Memuaskan Emosi & 8 & 26,7 & 5 & 33,3 & 13 & 28,9 \\
\hline $\begin{array}{l}\text { Mempertahankan } \\
\text { Gengsi }\end{array}$ & 5 & 16,7 & 2 & 13,3 & 7 & 15,6 \\
\hline $\begin{array}{l}\text { MenghukumMemberi } \\
\text { Pelajaran }\end{array}$ & 0 & 0 & 1 & 6,7 & 1 & 2,2 \\
\hline Total & 30 & 100 & 15 & 100 & 45 & 100 \\
\hline
\end{tabular}

Tabel 21 menunjukkan responden laki-laki cenderung memilih membela diri atau teman $(56,7$ persen) sebagai tujuan berperilaku agresi daripada responden perempuan (46,7 persen) namun responden perempuan lebih bertujuan untuk memuaskan emosi (33,3 persen) dibandingkan responden laki-laki (26,7 persen) bahkan responden perempuan cenderung memilih tujuan 
menghukum/memberi pelajaran $(6,7$ persen $)$ dibandingkan responden laki-laki yang tidak sama sekali. Hal ini mungkin disebabkan responden perempuan yang cenderung sering menonton film kekerasan dibandingkan responden laki-laki.

5. Adegan Film yang Berkesan Ketika Berperilaku Agresi

Ada sebesar 8,9 persen yang menyatakan cenderung terdapat kesan adegan film ketika melakukan perilaku agresi. Responden laki-laki lebih banyak menyatakan kecenderungan ada kesan ketika melakukan perilaku agresi (10 persen) daripada responden perempuan (6,7 persen). Adegan film yang paling berkesan adalah ketika adegan perkelahian, baik itu memukul atau menendang.

6. Perasaan Responden yang Timbul Setelah Berperilaku Agresi

Tabel 22. Jumlah dan Persentase Responden Berdasarkan Perasaan yang Timbul Setelah Berperilaku Agresi

\begin{tabular}{|l|c|c|c|c|c|c|}
\hline Perasaan yang & \multicolumn{4}{|c|}{ Jenis Kelamin } & \multicolumn{3}{c|}{ Total } \\
\cline { 2 - 6 } Timbul Setelah & Laki-Laki & \multicolumn{2}{|c|}{ Perempuan } & \multicolumn{2}{c|}{} \\
\cline { 2 - 6 } Berperilaku Agresi & n & $\%$ & n & $\%$ & n & $\%$ \\
\hline Tidak Tentu & 13 & 43,3 & 8 & 53,3 & 21 & 46,7 \\
\hline Tidak Ada & 2 & 6,7 & 0 & 0 & 2 & 4,4 \\
\hline Senang & 2 & 6,7 & 0 & 0 & 2 & 4,4 \\
\hline Puas & 7 & 23,3 & 2 & 13,3 & 9 & 20 \\
\hline Menyesal & 6 & 20 & 5 & 33,3 & 11 & 24,4 \\
\hline Total & 30 & 100 & 15 & 100 & 45 & 100 \\
\hline
\end{tabular}

Tabel di atas menunjukkan bahwa umumnya perasaan responden yang timbul setelah melakukan perilaku agresi adalah tidak tentu (46,7 persen). Perasaan puas yang cenderung timbulkan responden laki-laki (23,3 persen) lebih tinggi dibandingkan responden perempuan (13,3 persen). Perasan senang (6,7 persen) dan tidak ada (6,7 persen) umumnya lebih ditampilkan responden laki-laki daripada responden perempuan yang tidak sama sekali sedangkan perasaan menyesal responden perempuan lebih tinggi (33,3 persen) dibandingkan responden laki-laki (20 persen). Hal ini mungkin karena perasaan halus yang dimiliki perempuan dibandingkan laki-laki.

7. Ikhtisar hubungan perilaku agresi dengan jenis kelamin

Tabel 23. Jumlah dan Persentase Responden Berdasarkan Intensitas Perilaku Agresi dengan jenis kelamin

\begin{tabular}{|l|c|c|c|c|c|c|}
\hline \multirow{3}{*}{ Intensitas Perilaku Agresi } & \multicolumn{4}{|c|}{ Jenis Kelamin } & \multicolumn{2}{c|}{ Total } \\
\cline { 2 - 7 } & Laki-Laki & \multicolumn{2}{|c|}{ Perrempuan } & \multicolumn{2}{c|}{} \\
\cline { 2 - 7 } & $\mathrm{n}$ & $\%$ & $\mathrm{n}$ & $\%$ & $\mathrm{n}$ & $\%$ \\
\hline Intensitas Rendah & 8 & 26,7 & 8 & 53,3 & 16 & 35,6 \\
\hline Intensitas Sedang & 19 & 63,3 & 7 & 46,7 & 26 & 57,8 \\
\hline Intensitas Tinggi & 3 & 10 & 0 & 0 & 3 & 6,7 \\
\hline Total & 30 & 100 & 15 & 100 & 45 & 100 \\
\hline
\end{tabular}

Tabel 23 menunjukkan bahwa responden laki-laki cenderung intensitas perilaku agresinya tinggi (10 persen) dibandingkan dengan responden perempuan. intensitas sedang pada perilaku agresi umumnya lebih banyak responden laki-laki $(63,3$ persen $)$ dibandingkan responden perempuan (46,7 persen) namun pada intensitas rendah responden perempuan lebih tinggi (53,3 persen) daripada responden lakilaki (26,7 persen).

\section{Hubungan Antara Perilaku Agresi Remaja denganFaktor Personal (Jenis Kelamin), Perilaku Menonton Film Kekerasan, dan Faktor Situasional}

Tabel 24. Jumlah dan Persentase Responden Berdasarkan Hubungan Antara Perilaku agresi dengan Jenis Kelamin, Perilaku Menonton Film, dan Faktor Situsional

\begin{tabular}{|c|c|c|c|c|c|c|c|c|c|c|c|c|c|c|}
\hline \multirow[t]{3}{*}{$\begin{array}{l}\text { Perilaku } \\
\text { Agresi }\end{array}$} & \multicolumn{4}{|c|}{ Jenis Kelamin } & \multicolumn{4}{|c|}{$\begin{array}{l}\text { Perilaku Menonton } \\
\text { Film }\end{array}$} & \multicolumn{6}{|c|}{ Faktor Situsional } \\
\hline & \multicolumn{2}{|c|}{$\begin{array}{l}\text { Laki- } \\
\text { Laki }\end{array}$} & \multicolumn{2}{|c|}{ Perempuan } & \multicolumn{2}{|c|}{$\begin{array}{l}\text { Intensitas } \\
\text { Rendah }\end{array}$} & \multicolumn{2}{|c|}{$\begin{array}{l}\text { Intensitas } \\
\text { Tinggi }\end{array}$} & \multicolumn{2}{|c|}{$\begin{array}{l}\text { Intensitas } \\
\text { Rendah }\end{array}$} & \multicolumn{2}{|c|}{$\begin{array}{l}\text { Intensita } \\
\text { s Sedang }\end{array}$} & \multicolumn{2}{|c|}{\begin{tabular}{|l} 
Intensitas \\
Tinggi \\
\end{tabular}} \\
\hline & $\mathrm{n}$ & $\%$ & $\mathrm{n}$ & $\%$ & $\mathrm{n}$ & $\%$ & $\mathrm{n}$ & $\%$ & n & $\%$ & $\mathrm{n}$ & $\%$ & $\mathrm{n}$ & $\%$ \\
\hline $\begin{array}{l}\text { Intensitas } \\
\text { Rendah }\end{array}$ & 8 & 26,7 & 8 & 53,3 & 35 & 7 & 9 & 36 & 2 & 33,3 & 13 & 38,2 & 1 & 20 \\
\hline $\begin{array}{l}\text { Intensitas } \\
\text { Sedang }\end{array}$ & 19 & 63,3 & 7 & 46,7 & 13 & 65 & 13 & 52 & 4 & 66,7 & 21 & 61,8 & 1 & 20 \\
\hline $\begin{array}{l}\text { Intensitas } \\
\text { Tinggi }\end{array}$ & 3 & 10 & 0 & 0 & 0 & 0 & 3 & 12 & 0 & 0 & 0 & 0 & 3 & 60 \\
\hline Total & 30 & 100 & 15 & 100 & 20 & 100 & 25 & 100 & 6 & 100 & 34 & 100 & 5 & 100 \\
\hline
\end{tabular}

Tabel di atas menunjukkan umumnya hanya responden laki-laki yang mempunyai perilaku agresi dengan intensitas tinggi (10 persen) daripada responden perempuan namun responden perempuan mempunyai perilaku agresi dengan intensitas rendah lebih banyak (53,3 persen) dibandingkan responden laki-laki (26,7 persen). Umumnya hanya perilaku menonton dengan intensitas tinggi yang memiliki persentase perilaku agresi dengan intensitas tinggi (12 persen) begitu juga dengan faktor situasional hanya yang berintensitas tinggi yang memiliki persentase perilaku agresi dengan intensitas tinggi (60 persen)

Tabel 25.Nilai Korelasi danNilai Signifikan Berdasarkan Hubungan Antara Perilaku agresi dan Faktor yang Mempenganuhi

\begin{tabular}{|c|c|c|c|}
\hline \multirow{2}{*}{\multicolumn{2}{|c|}{$\begin{array}{l}\text { Falktor yang } \\
\text { Mempengaruhi }\end{array}$}} & \multicolumn{2}{|c|}{ Perilaku Agresi } \\
\hline & & Sig. & Value \\
\hline \multicolumn{2}{|c|}{ Jenis Kelamin } & 0,137 & 0,285 \\
\hline \multicolumn{2}{|c|}{$\begin{array}{l}\text { Intensitas Menonton Film } \\
\text { Kekerasan }\end{array}$} & 0,555 & 0,160 \\
\hline \multirow{3}{*}{$\begin{array}{l}\text { Jenis Film } \\
\text { Kekerasan }\end{array}$} & Film Action & 0,399 & 0,198 \\
\hline & $\begin{array}{l}\text { Film } \\
\text { Perang }\end{array}$ & 0,245 & 0,243 \\
\hline & Filmhoror & 0,589 & 0,145 \\
\hline \multicolumn{2}{|c|}{$\begin{array}{l}\text { Perilaku MenontonFilm } \\
\text { Kekerasan }\end{array}$} & 0,256 & 0.239 \\
\hline \multicolumn{2}{|c|}{$\begin{array}{l}\text { Intensitas Perilahu Agresi } \\
\text { diLingkungan Keluarga }\end{array}$} & $0,000^{8}$ & 0,653 \\
\hline \multicolumn{2}{|c|}{$\begin{array}{l}\text { Intensitas Perilaku Agresi } \\
\text { di Lingkungan Tempat } \\
\text { Tinggal }\end{array}$} & $0,001^{8}$ & 0,544 \\
\hline \multicolumn{2}{|c|}{$\begin{array}{l}\text { Intensitas Perilahu Agresi } \\
\text { oleh Teman }\end{array}$} & $0,034^{88}$ & 0,434 \\
\hline \multicolumn{2}{|c|}{ Faktor Situasional } & $0,000^{8}$ & 0,604 \\
\hline
\end{tabular}

Keterangan:

1. Tanda "* "menunjukkan hubungan signifikan pada $\alpha 0,01$

2. Tanda "**" menunjukkan hubungan signifikan pada $\alpha 0,05$

3. Data dianalisis menggunakan Chi Square test

Dari tabel di atas dapat disimpulkan perilaku menonton film kekerasan tidak memiliki hubungan signifikan dengan perilaku agresi remaja. Tabel di atas menunjukkan faktor intensitas perilaku agresi di lingkungan keluarga memiliki hubungan signifikan dengan perilaku agresi remaja. Hal ini ditunjukkan oleh nilai $\mathrm{P}$-Value $=0,000$ dengan nilai korelasi 0,653 pada $\alpha 0,01$ dengan selang 
kepercayaan 99 persen sehingga mempunyai hubungan pengaruh di mana semakin tinggi perilaku agresi di lingkungan keluarga maka semakin tinggi perilaku agresi yang dilakukan remaja. Faktor intensitas perilaku agresi di lingkungan tempat tinggal memiliki hubungan signifikan dengan perilaku agresi remaja. Hal ini ditunjukkan oleh nilai $\mathrm{P}$-Value $=0,001$ dengan nilai korelasi 0,544 pada $\alpha$ 0,01 dengan selang kepercayaan 99 persen sehingga mempunyai hubungan pengaruh. Faktor intensitas perilaku agresi oleh teman memiliki hubungan signifikan dengan perilaku agresi remaja.

Hal ini ditunjukkan oleh nilai $\mathrm{P}$-Value $=0,034$ dengan nilai korelasi 0,434 pada $\alpha \quad 0,05$ dengan selang kepercayaan 95 persen sehingga mempunyai hubungan pengaruh. Faktor situasional juga memiliki hubungan signifikan dengan perilaku agresi remaja. Hal ini ditunjukkan oleh nilai $\mathrm{P}-$ Value $=0,000$ dengan nilai korelasi 0,604 pada $\alpha$ 0,01 dengan selang kepercayaan 99 persen sehingga mempunyai hubungan pengaruh. Faktor jenis kelamin, intensitas menonton film kekerasan, dan jenis film kekerasan (film action, film perang, dan film horor) tidak memiliki hubungan signifikan dengan perilaku agresi remaja.

\section{KESIMPULAN DAN SARAN}

\section{Kesimpulan}

Dari penelitian yang dilakukan, dapat disimpulkan bahwa intensitas remaja dalam menonton film kekerasan pada umumnya jarang daripada intensitas sering. Umumnya intensitas sering dalam menonton film kekerasan lebih banyak responden perempuan dibandingkan responden laki-laki. Sementara jenis film kekerasan yang lebih sering ditonton adalah film horor. Responden laki-laki memiliki kecenderungan menonton film horor, film action/laga, film perang, dan film silat sedangkan responden wanita memiliki kecenderungan menonton film horor dan film misteri/detektif. Media film yang sering digunakan oleh responden adalah televisi dan VCD/DVD Player. Pada umumya responden mendapatkan film kekerasan dengan cara membelinya. Hal ini disebabkan murah dan mudahnya DVD bajakan yang diperjualbelikan. Harga DVD bajakan yang diperjualbelikan berkisar Rp5000-Rp7000 perkeping. Tempat menjual DVD bajakan mudah ditemui di dekat sekolah maupun di sekitar pasar. Sarana yang dimiliki di rumah untuk menonton film kekerasan adalah televisi dan VCD/DVD Player. Hal ini disebabkan televisi dan VCD/DVD Player bukan merupakan barang mewah lagi.

Pada penelitian dapat dilihat bahwa responden laki-laki memiliki perilaku agresi dengan intesitas yang lebih tinggi daripada responden perempuan. Responden perempuan cenderung mengekspresikan perilaku agresi verbal seperti mengejek. Responden laki-laki cenderung mengekspresikan perilaku agresi verbal dan perilaku agresi fisik. Perilaku agresi verbal yang cenderung responden laki-laki ekspresikan adalah perilaku mengejek. Perilaku agresi fisik yang dilakukan responden laki-laki cenderung memukul sedangkan responden perempuan cenderung melakukan perilaku agresi fisik menampar. Perilaku agresi dengan menggunakan alat hanya terjadi pada responden laki-laki.
Responden laki-laki cenderung melakukan perilaku agresi bersifat lebih kejam terhadap teman dan orang lain sedangkan responden perempuan melakukan perilaku agresi umumnya kepada sesama teman. Umumnya reaksi responden ketika ada yang berperilaku agresi adalah bertahan atau melindungi diri. Responden laki-laki cenderung memilih bertahan dan melindungi diri ketika ada yang berperilaku agresi kepadanya sedangkan responden perempuan lebih memilih mengalah atau tidak mencari keributan namun lebih banyak responden perempuan yang akan menyerang/balas menganggu ketika ada yang berperilaku agresi. Responden laki-laki cenderung memilih membela diri atau teman sebagai tujuan berperilaku agresi daripada responden perempuan namun responden perempuan lebih bertujuan untuk memuaskan emosi bahkan responden perempuan cenderung memilih tujuan menghukum/memberi pelajaran dibandingkan responden laki-laki yang tidak sama sekali. Hal ini mungkin disebabkan responden perempuan yang cenderung lebih banyak menonton film kekerasan dengan intensitas sering dibandingkan responden laki-laki. Responden laki-laki lebih banyak menyatakan kecenderungan ada kesan ketika melakukan perilaku agresi daripada responden perempuan. Adegan film yang paling berkesan adalah ketika adegan perkelahian, baik itu memukul atau menendang. Umumnya perasaan responden yang timbul setelah melakukan perilaku agresi adalah tidak tentu.

Perilaku menonton film kekerasan tidak memiliki hubungan signifikan dengan perilaku agresi remaja. Faktor jenis kelamin, intensitas menonton film kekerasan, dan jenis film kekerasan (film action, film perang, dan film horor) tidak memiliki hubungan signifikan dengan perilaku agresi remaja. faktor intensitas perilaku agresi di lingkungan keluarga memiliki hubungan signifikan dengan perilaku agresi remaja pada $\alpha 0,01$ dengan selang kepercayaan 99 persen sehingga mempunyai hubungan pengaruh, di mana semakin tinggi perilaku agresi di lingkungan keluarga maka semakin tinggi perilaku agresi yang dilakukan remaja. Faktor intensitas perilaku agresi di lingkungan tempat tinggal memiliki hubungan signifikan dengan perilaku agresi remaja pada $\alpha 0,01$ dengan selang kepercayaan 99 persen sehingga mempunyai hubungan pengaruh.

Faktor intensitas perilaku agresi oleh teman memiliki hubungan signifikan dengan perilaku agresi remaja pada $\alpha$ 0,05 dengan selang kepercayaan 95 persen sehingga mempunyai hubungan pengaruh. Faktor situasional juga memiliki hubungan signifikan dengan perilaku agresi remaja pada $\alpha$ 0,01 dengan selang kepercayaan 99 persen sehingga mempunyai hubungan pengaruh. Berdasarkan hasil analisis data dengan menggunakan Chi Square dapat disimpulkan bahwa hipotesis $\mathrm{H} 0$ yang menyatakan bahwa perilaku menonton film kekerasan tidak mempunyai hubungan pengaruh terbukti.

\section{Saran}

Berdasarkan hasil penelitian ini maka saran yang dapat diberikan yaitu:

a. Walaupun berdasarkan penelitian ini perilaku kekerasan tidak memiliki hubungan terhadap 
perilaku agresi, pemerintah tetap harus memperhatikan isi film yang ditampilkan agat tidak mengarahkan remaja kepada perilaku agresi.

b. Orangtua harus menciptakan lingkungan yang tidak sering mengexpos perilaku agresi baik dalam baik dalam perilaku agresi verbal dan fisik termasuk juga mengurangi intensitas menonton film kekerasan.

c. Perlunya penelitian yang sama dengan mengambil responden lebih banyak khususnya remaja-remaja yang benar-benar terlibat dalam perilaku-perilaku kekerasan yang sudah mengarah pada kriminalitas.

\section{DAFTAR PUSTAKA}

Abidin, Zainal. 2005. Penghakiman Massa. Jakarta : Erlangga.

Apollo \& Djamaludin A. 2003, Hubungan Antara Intensitas Menonton Tayangan Televisi Berisi Kekerasan, Persepsi Terhadap Keharmonisan Keluarga, Jenis Kelamin, dan Tahap Perkembangan Dengan Kecenderungan Agrestivitas Remaja, Jurnal SOSIOHUMANIKA, vol.16.

Arikunto, S. 2002. Prosedur Suatu Penelitian: Pendekatan Praktek (Edisi Kelima). Jakarta: Rineka Cipta.

Atwater, E. (1992). Adolescence. Toronto Canada Inc: Prectice-Hall.

Effendy, Onong. 2001. Ilmu Komunikasi Teori dan Praktek. Bandung: PT Remaja Rosdakarya.

Evita, Cecilia. 2007. Hubungan Antara Perilaku Menonton Film Percintaan Dengan Sikap Remaja Terhadap Perilaku Berpacaran. [Skripsi]. Bogor [ID]: Institut Pertanian Bogor. 97 hal.

Fagan, R. 2006, Counseling and Treating Adolescents with Alcohol and Other Substance Use Problems and their Family, The Family Journal: Counseling therapy For Couples and Families, vol.14., no.4, hal. 326-333.

Gunarsa, S. D. 1989. Psikologi Perkembangan: Anak dan Remaja. Jakarta: BPK. Gunung Mulia.

Hurlock, E.B. 1991. Psikologi Perkembangan Suatu Pendekatan Sepanjang Rentang Kehidupan (Terjemahan oleh Istiwidayanti dan Soedjarwo). Jakarta : Penerbit Erlangga.

Koeswara, E. 1998. Agresi Manusia. Bandung : PT Erasco.

McQuail, Dennis. 1987. Teori Komunikasi Massa Suatu Pengantar (Edisi kedua). Jakarta: Erlangga.

Mongks, F. J. , Knoers, A. M. P. , \& Haditono, S. R. 2000. Psikologi Perkembangan: Pengantar dalam berbagai bagiannya. Yogyakarta: Gadjah Mada University Press.

Mulyana, Deddy. 2004. Ilmu Komunikasi Suatu Pengantar.Bandung: PT Remaja Rosdakarya.
Notoatmodjo, S. 2003. Pendidikan dan Perilaku Kesehatan. Jakarta : Rineka Cipta

Nuryoto, S. 1992. Kemandirian Remaja Ditinjau dari Tahap Perkembangan, Jenis Kelamin dan Peran Jenis. [Disertasi]. Yogyakarta[ID]: Fakultas Psikologi Universitas Gadjah Mada.

Priliantini, A. 2008, Hubungan Antara Gaya Manajemen Konflik Dengan Kecenderugan Perilaku Agresif Narapidana Usia Remaja Di Lapas Anak Pria Tangerang, Jurnal Psiko-Edukasi, vol. 6, hal. 1020.

Rakhmat, Jalaluddin. 2005. Psikologi Komunikasi Massa. PT. Remaja Rosda Karya, Bandung.

Sarwono, Sariito Wirawan. 2004. Psikologi Remaja. Edisi Revisi. Jakarta:PT Raja Grafindo Persada.

Scheneider, Alexander. A. 1955. Personal Adjusment and Mental Healty. New York : Holt, Rinehart dan winston.

Sugiyono. 2004. Statistika Untuk Penelitian (Edisi Keenam).Bandung: Alfabeta

Suharto. 2006. Hubungan Pola Menonton Berita Kriminal di Televisi dengan Perilaku Remaja.[Skripsi].Bogor [ID]: Institut Pertanian Bogor. 110 hal.

Sumarno, Marselli. 1996. Dasar-Dasar Apresiasi Film. Jakarta: PT Gramedia Widiasarana Indonesia.

Tumengkol, Ida. 2009,Tayangan Kekerasan di Televisi dan Perilaku Pelajar, Jurnal Penelitian Komunikasi dan Pembangunan, vol. 1, no. 10, hal. 88-103.

Valentine H, Virgin. 2009. Efek Berita Kriminal Terhadap Perilaku Khalayak Remaja (Kasus SMP Taman Siswa, Jakarta Pusat). [Skripsi].Bogor [ID]: Institut Pertanian Bogor. 99 hal.

Widiastuti, Wahyu. 2002, Adegan Kekerasan di Televisi Terhadap Perilaku Agresif Remaja Perkotaan,Jurnal Penelitian UNIB,vol.VIII , no. 3, hal. 140-143. 